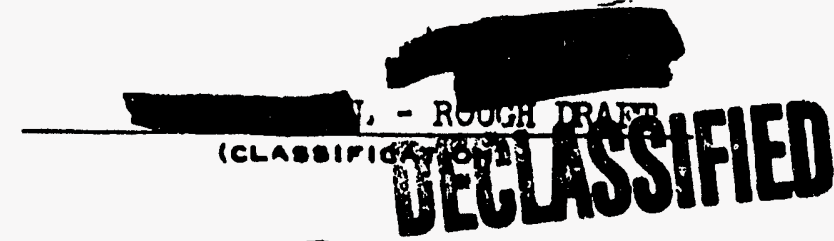 GENERAL ELETRIC
}

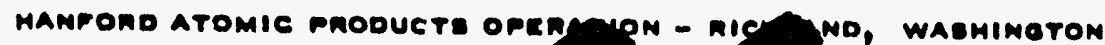

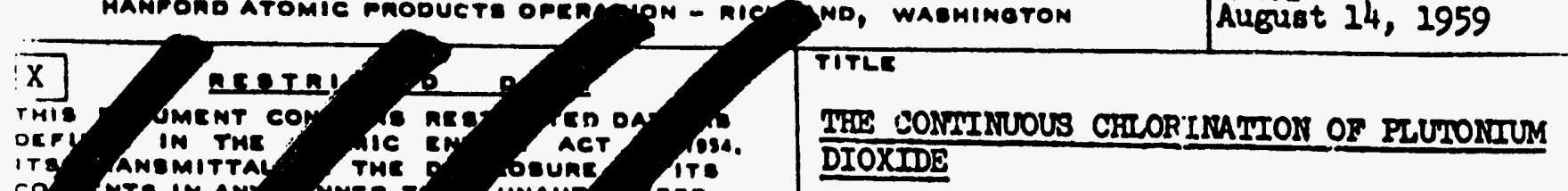

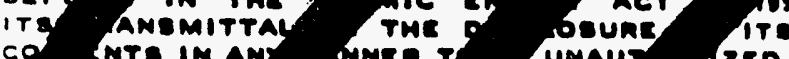

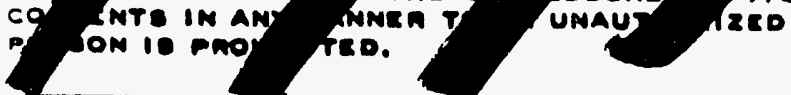

Jormzn ofricial CLABDifICo InFONMATION

THID MATERIAL CONTAINE INTONMATION AFFECTINE

THE MATIOMAL DEFENER OP TME UNITED ETATE

WITMIN THE MEANING OF THE CEPIONACR LAWE.

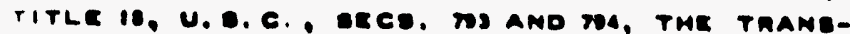

MISEION OR ARVELATION OF WMICH IN ANY MANNER

TO AN UMAUTMONIzED PIESOON IS PROMIDITEO DY

I AW.

mis $\infty$

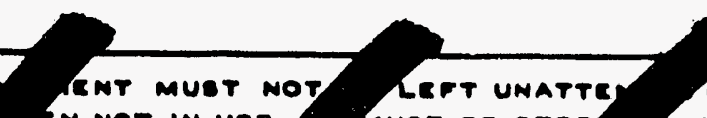

ro it IN MOT IN UDE,

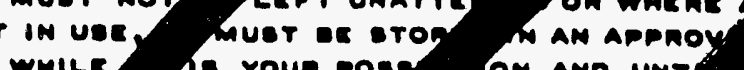
10 roun pose hON AND UNT

AnEA. WMILE

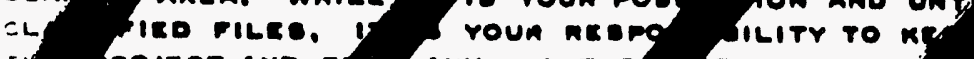

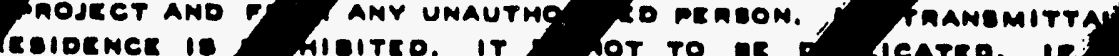

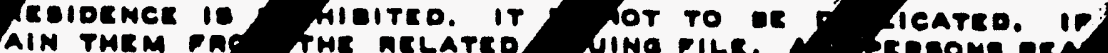
THE THE nELATEO GING FILE.

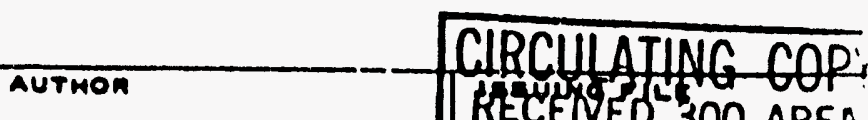

CHCUAREN NOS

HW-61569 RD

urto u a, sukli:

ornize and copr no.

A - 2

DATE

August 14, 1959

THR CONMINUOUS CHLORINATION OF PLUTONIUM

M. J. Rosmusson

AUG3 11959

Rtiunir 10

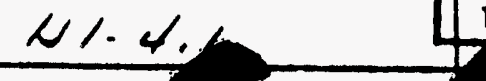

TECHNICAL INIUKMAY YII.

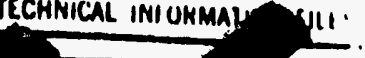

SN maY b a withe

Mesipt Acers Sekto nentzo

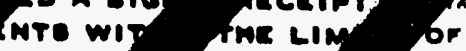
AnD etre

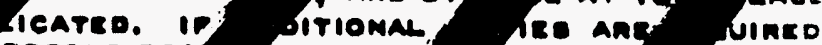

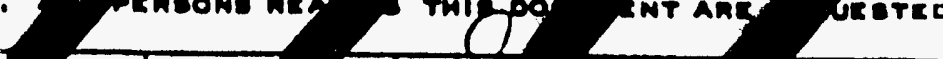

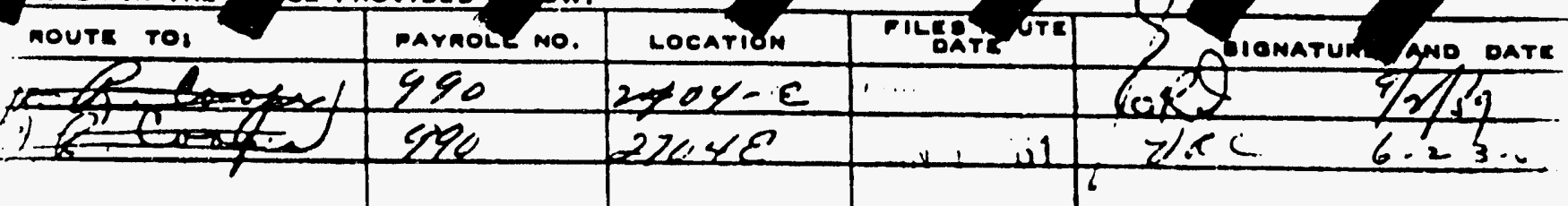

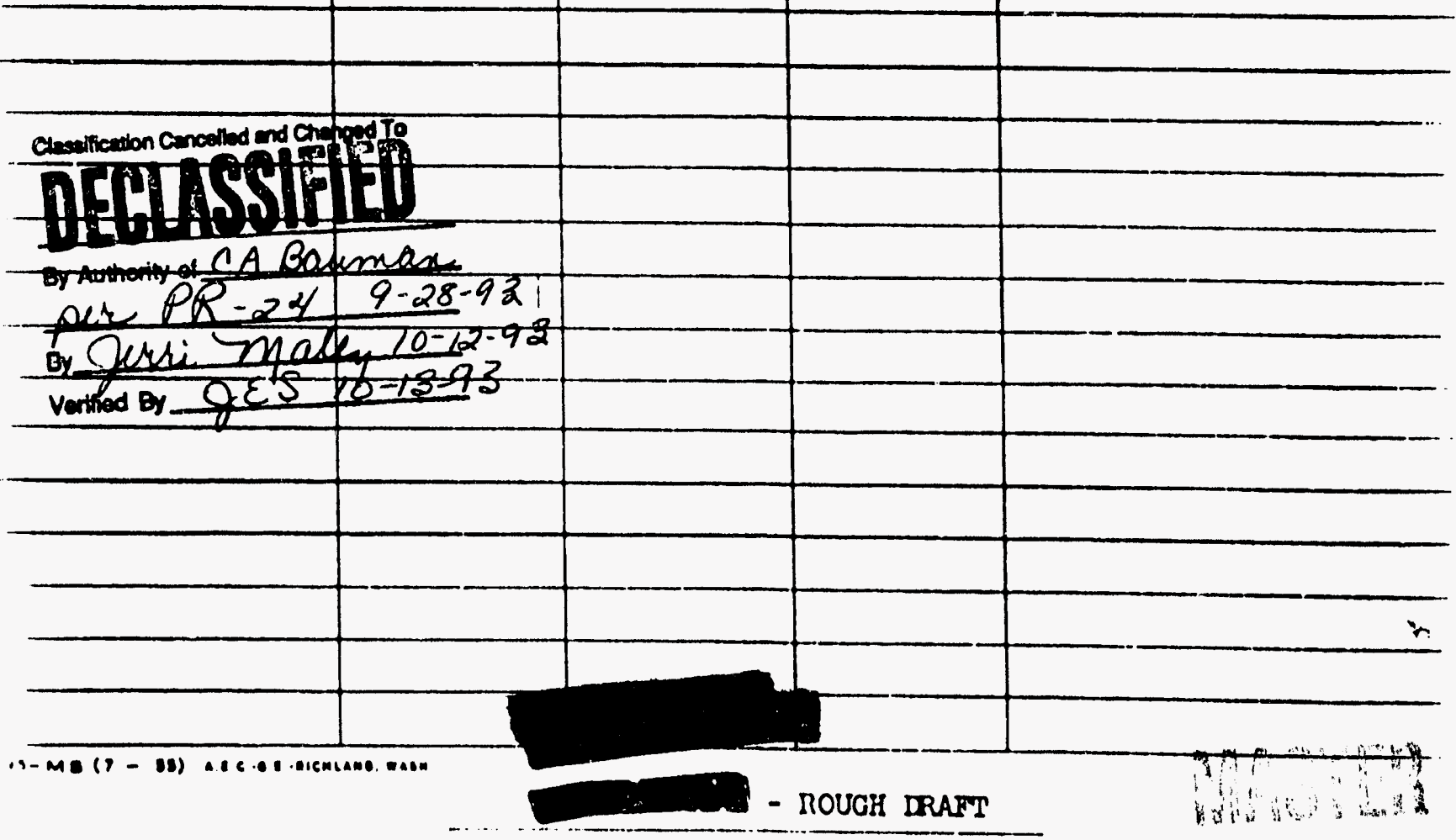




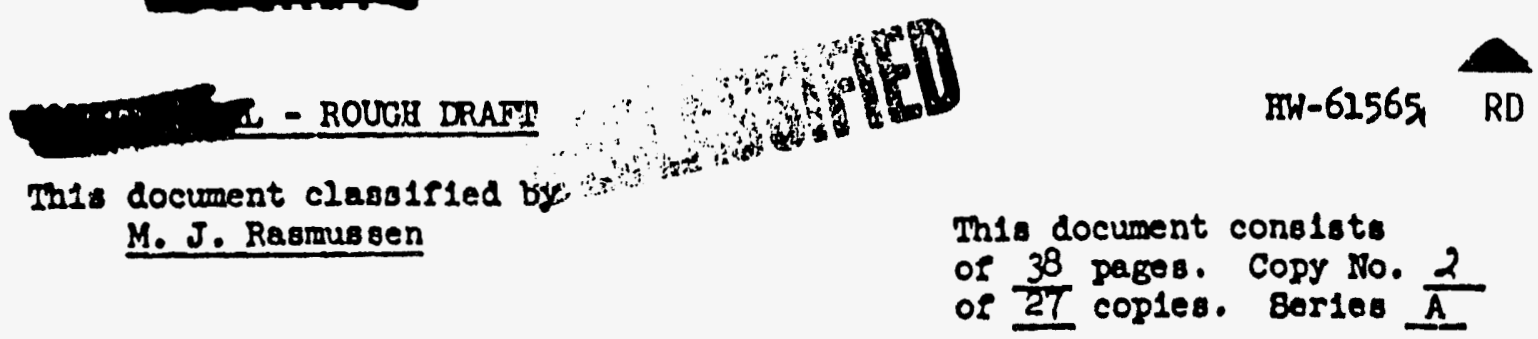

copy I of 1. SERIES M.I

-

\section{THE CONTINUOUS CHLORINATION OF FLUTONIUM DIOXIDE}

By

M. J. Rasmussed

234-5 Development Operat1on Research and Eng1neer1ng Operaticn Chemlcal Processing Department

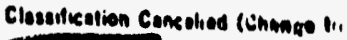

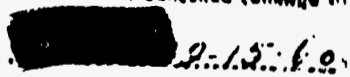

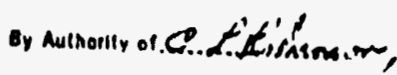

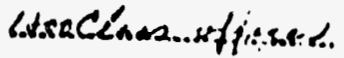

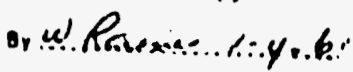

August 14, 1959

HANTORD ATOMIC PRODUCTS OPERATION RICHLAND, WASEINGTON

Operated for the Atanic Energy Camisolon by the

General Elentric Company under Contract Al(45.3) 4.350

\section{DISCLAIMER}

This report was prepared as an account of work sponsored by an agency of the United States Government. Neither the United States Government nor any agency thereof, nor any of their employees, makes any warranty, express or implied, or assumes any legal liability or responsibility for the accuracy, completeness, or usefulness of any information, apparatus, product, or process disclosed, or represents that its use would not infringe privately owned rights. Reference herein to any specific commercial product, process, or service by trade name, trademark, manufacturer, or otherwise does not necessarily constitute or imply its endorsement, recom. mendation, or favoring by the United States Government or any agency thereof. The views and opinions of authors expressed herein do not necessarily state or reflect those of the United States Government or any agency thereof.

\section{-}
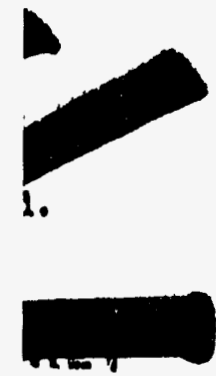


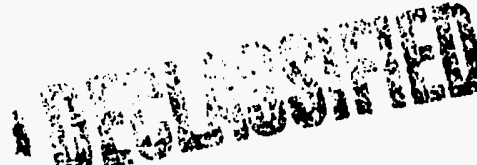

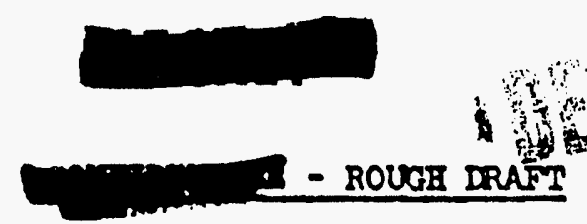

$-20$

\section{DISIRIBUTION}

Copy Mumber

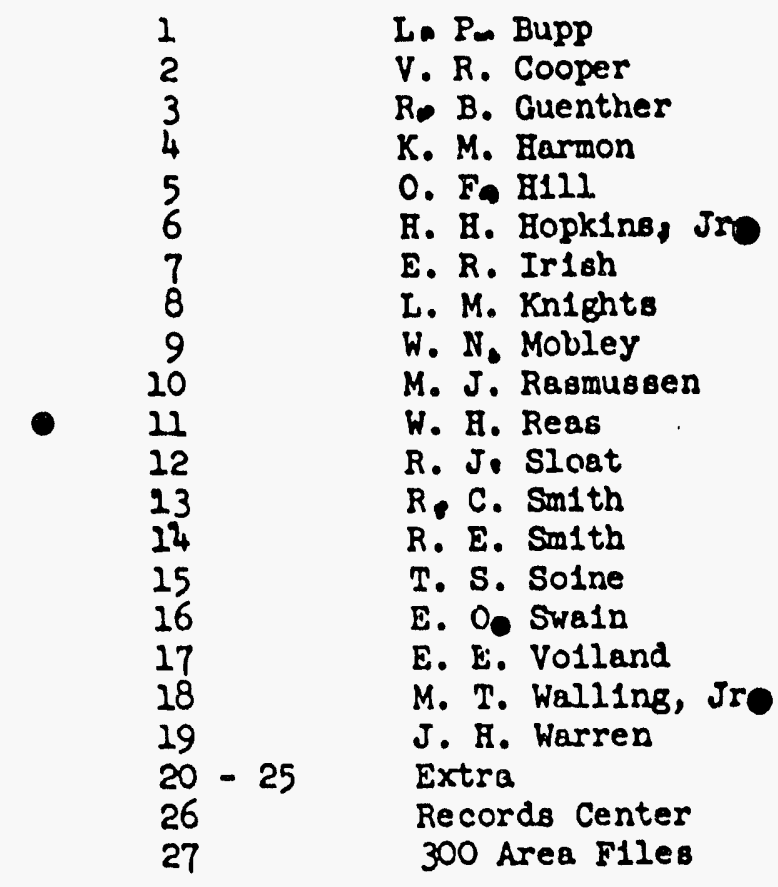




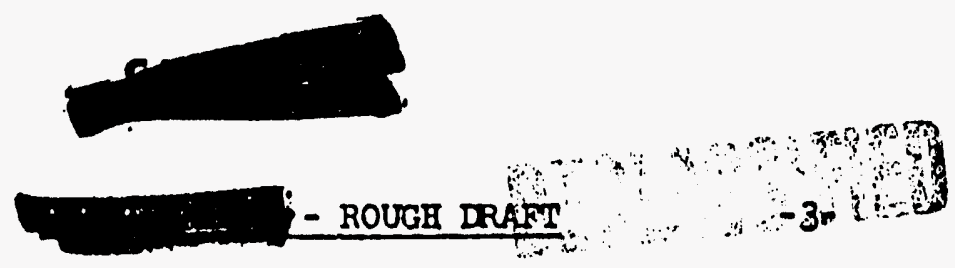

TABTE OF CONHENTS

$\underline{P e g e}$

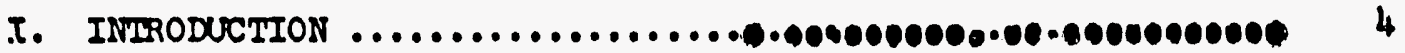

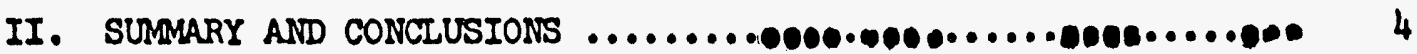

III. DISCUSSION

A. Chlorination of Plutonlum Dioxide

1. Feas1b1l1ty ..............

2. Chlorinat1on Chem_btry ...........

( 3. Small Batch Studles ........................

4. Large Batch Chlorination ..........................

5. Cont1nuous Chlorination - Pyrex Reactor ............

6. Cont1nuous Chlorination - Demonstration Reactor ....

7. Mater1als of Construct1on ...................

B. Chlorination Exhaust Gas Disposal

1. Flitering .............80.......4800.....8400.0

2. Exhaust Ges Compos1t1on ......................

3. Exhaust Ges Neutral1zat1on ....................

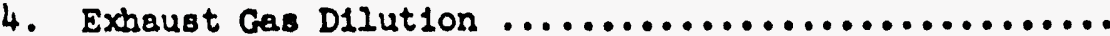

5. Recovery of Phosgene ........................

C. Character1st1cs of Plutonfum Tr1chlor1de

1. Stab1l1ty ............................... 17

2. Color .................................... 18

3. Eydrat1on ................................ 18

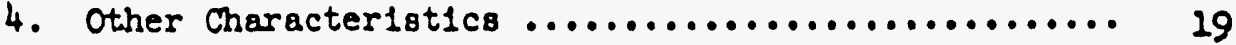

5. Pur1ty .................................. 20

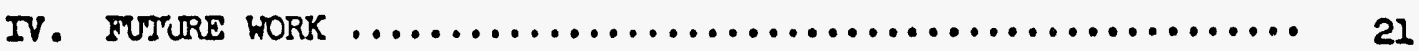

V. ACKCNOWLEDGEMENTS ................................ 21

VI. BIELIOCRAPHY $\ldots \ldots \ldots \ldots \ldots \ldots \ldots \ldots \ldots \ldots \ldots \ldots \ldots \ldots \ldots \ldots \ldots \ldots \ldots \ldots \ldots \ldots \ldots \ldots$

VII. APTENDIX ..................................... 27

VIII. FIGURES $\ldots \ldots \ldots \ldots \ldots \ldots \ldots \ldots \ldots \ldots \ldots \ldots \ldots \ldots \ldots \ldots \ldots \ldots \ldots \ldots \ldots \ldots \ldots \ldots \ldots \ldots \ldots . \ldots$ 


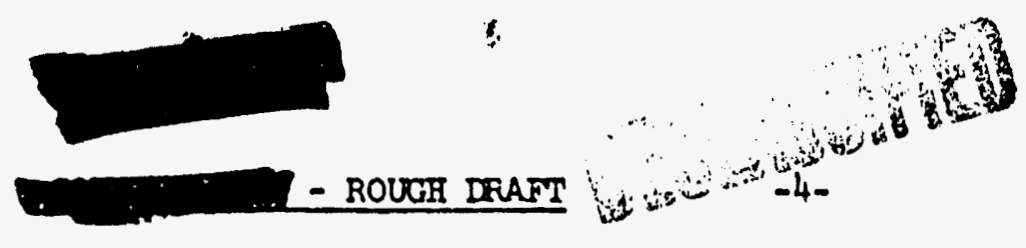

$H W-6156 \% \widehat{R D}$

TFE CONIINUOUS CHLORINATION OF PLUIONIUM DIOXIDE

\section{INLRODE:CTION}

Previous reports on the clilorination of plutonfum dioxdde describe numerous small-scale experlments and a few falr-sized batch preparations. The chemlitry of chlorination by numerous reagents is covered, but no process had recelved sufficlent study for large-scale preparation of anhydrous plutonlum trichlorlde. The l1terature search revealed no extensive studies on chlorination rates, exhaust gas illterlng, atmospheric requirements, reactor mater1als, etc. A program was undertaken to select a chlorination process, to develop the necessary information for defining operating conditions and equipment specifications, and then to demonstrate the operation of the procesa.

\section{SUMMARY AND CONCLUSIONS}

The conversion of plutonlum dioxide to anhydrous plutonlum trichloride has been thoroughly demenstrated on a large scale in both batch and cont1mous processes. Operating rates and process requirements were developed in demonstrating the continuous process. Fhosgene gas at 450 - $500 \mathrm{C}$ is found to be the most reactive agenl. Safe handling of phosgene was dewonstrated. LOW corrosion rates on selected alloys indlcate durablilty of equipwert and sat1ofactory chloride purity. Ceramic filters and noncorrosive plpe for exhaust gases are specifled.

Plutonfum trichloride remains anhydrous in als at dew point -20 cent1grade. Eydration rates for h1gher humfdities are reported.

Neutron emission from plutonium trichloride 18 signiflcantly less than from plutonlum tetrafluoride.

\section{DISCUSSION}

\section{A. Chlorination of Plutonlum Dioxide}

1. Feas1b1l1ty

The chlorination of plutonfum dioxide has bern accouplished by numerous investigator $(1,2,3,4,5,6,7,8,9,10,11)$ utilizing a varlety of reagents and conditions. Many of these chlarinations were exploratory, minute-scale experiments in plutonium chemistry. Some were moderately-slzed batch chlorinations to provlde plutonium trichloride for subsequent experiments. The present study was planned(12) to develop a process whlch could be applied on a largo ocale. The process development was deliberately polnted to ut1l1zo procedures and equipment with which the invest1gators were alreid fam1l1ar.

An Interim ropirt (13) and this elnal report sumarize the work
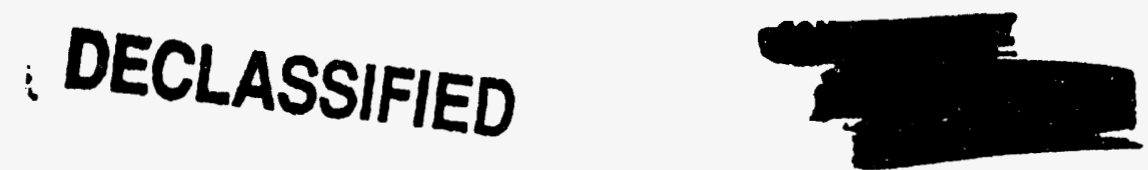


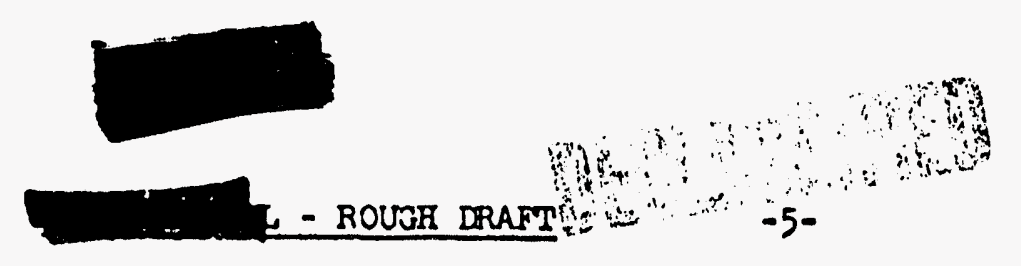

of numerous contributors (see section V). The reduction of plutonium trichlorfile and recovery of chlorice wastes are reported separately. (14)(15)

A chlorination process has been derunsirated on a large-batch scale and also developed Into a cont:inuous process. Over 52 kdlograms of plutonium trichlorida have lieen prepared during th1s invest1gation. Of this, about $19.7 \mathrm{~kg}$ were produced in cont1nuous units demonetrating the feasibility of continuous chlorination. The plutonfum trichloride quality was satiofactory and ylelded good metal in banb reduction tests. The metal produced fram properlyprepared plutionium was of satisfactory purity.

\section{Chlor1nat1on_Ctemistry}

Conversion of plutonium dioxide to plutonlum trichloride may proceed directly or stepwise v1a the oxychloride. Direct chlor1nation by carbon tetrachloride 18 indicated in equations a and $b$ :

$$
\begin{aligned}
& \text { a. } \mathrm{PuO}_{2}+\mathrm{CCl}_{4} \longrightarrow \mathrm{PuCl}_{3}+\mathrm{CO}_{2}+1 / 2 \mathrm{Cl}_{2} \\
& \text { 8. } \mathrm{PuO}_{2}+2 \mathrm{CCl}_{4} \longrightarrow \mathrm{PuCl}_{3}+2 \mathrm{COCl}_{2}+1 / 2 \mathrm{Cl}_{2}
\end{aligned}
$$

The difference in these reactions in in the by-product gases. Fhosgene is knowa to be present; and, therefore, may 1tself chlorinate the oxtde directly.

$$
\text { c. } \mathrm{PuO}_{2}+2 \mathrm{COCl}_{2} \longrightarrow \mathrm{PuCl}_{3}+2 \mathrm{CO}_{2}+1 / 2 \mathrm{Cl}_{2}
$$

The presence of carbon monoxtde in the system has also been detected. This, with the chlorine, offers a fourth means of direct chlorination of the oxide.

d. $\mathrm{PuO}_{2}+2 \mathrm{CO}+3 / 2 \mathrm{Cl}_{2} \longrightarrow \mathrm{PuCl}_{3}+2 \mathrm{CO}_{2}$ act1ons.

Equations "e" through "g" Indicate stepwise chlorination re-

$$
\begin{aligned}
& \text { e. } \mathrm{PuO}_{2}+\mathrm{CCl}_{4} \longrightarrow \mathrm{PuOCl}+\mathrm{COCl}_{2}+1 / 2 \mathrm{Cl}_{2} \\
& \text { f. } \mathrm{PuO}_{2}+\mathrm{COCl}_{2} \longrightarrow \mathrm{PuOCl}+\mathrm{CO}_{2}+1 / 2 \mathrm{Cl}_{2} \\
& \text { g. } \mathrm{PuO}_{2}+\mathrm{CO}+1 / 2 \mathrm{Cl}_{2} \longrightarrow \mathrm{PuOCl}+\mathrm{CO}_{2} \\
& \text { h. } \mathrm{PuOCl}+\mathrm{CCl}_{4} \longrightarrow \mathrm{PuCl}_{3}+\mathrm{CO}+\mathrm{Cl}_{2} \\
& \text { 1. } \mathrm{PuOCl}+\mathrm{COCl}_{2} \longrightarrow \mathrm{PuCl}_{3}+\mathrm{CO}_{2} \\
& \text { j. } \mathrm{PuOCl}+\mathrm{CO}+\mathrm{Cl}_{2} \rightarrow \mathrm{PuCl}_{3}+\mathrm{CO}_{2}
\end{aligned}
$$

The carbon monoxide may be formed in the stepwise chlorination 

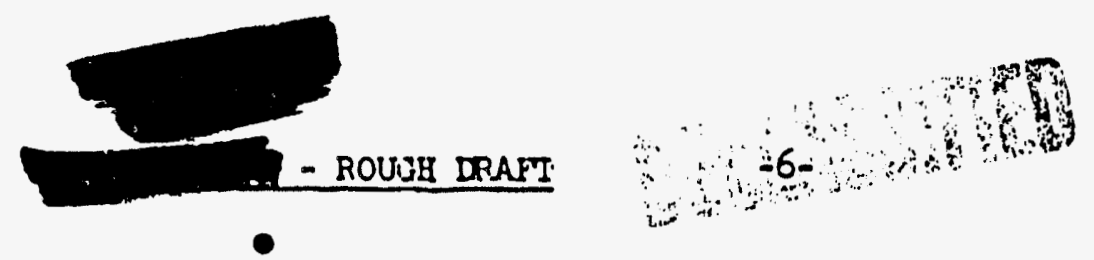

or by desociation of phosgene.

$$
\text { k. } \mathrm{COCl}_{2} \longrightarrow \mathrm{CO}+\mathrm{Cl}_{2}
$$

These reastions are typlcal for the many reagents which chlorinate piutonfun dloxdie. These are the reactions of most concern in the belected chlorination condit1ons. At blgher temperatures $(800 \mathrm{C})$, a volatile PuCl4 may be as intermedlate. Where insufflclent reducing agent 1s present, arother oxpchlor1de, Puocl2, 1s theor1zed. AB found in small batch studies, the principal reactions are direct formation of trickloride.

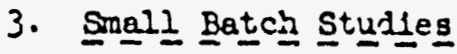

Chlorination studies were IImited to processes which showed most promise for application in a cont1nuous process or to investigation of varlables in these processes. Tolley (8) trled four reagents and recommended both carbon tetrachlorlde and phosgene at temperatures lower than other 1nrestigators.(1) $(4)(6)$

For small batch studies, N. S. W1ng used a one-1nch tube furnace and carbon tetrachloride. The carbon tetrachloride was warmed to $65 \mathrm{C}$ (bolling pilnt $76 \mathrm{C}$ ) by a water jacket, and carried as vapor in a stream of argon truough the furpace, a trap, and a caustic bubbler

Plutonlum dloxide in numerous small batches was ablorinated to study optimum temperature, chlorination rates, porder density, hydration rates, etc. Results on the 5 - 100 gram scale were good. A temperature of 450 - $500 \mathrm{C}$ for carbon tetrachlor 1de was recomended.

When plutonlum dioxide was treated wlth undlluted phosgene gas at the oame conditions, the chlorination was more rapid than with carbon tetrachloride. The surface of the powder was chlorinated in ten minutes. At $400-450 \mathrm{C}$, the effectiveness of the phosgene was about the same as the carbon tetrachloride at $450-500 \mathrm{C}$.

Several batches of plutonfum(IV) oxalate were successfully chlorinated w1th phosgene. On scme batches, conversion to oxide may have preceded chlorination. On one batch of plutonlum oxalate containling allghtly-leвs water than the monohydrate, chlorination with phosgene was completed at temperatures below $250 \mathrm{C}$ in reasonably short time. The trichloride was I1ght greenlob-blue, almost grey. One measurement of bulk dens1ty gave $1.6 \mathrm{~g} / \mathrm{cc}$.

The chlorlde powder was successfully reduced to metel. Further Inveat1gation of oxalate chlorination was not presued due to questions on disposal of the oxalate and on signtficance of the low density chloride.

Plutonfum dloxide prepared by calcination of plutonlum(IV)

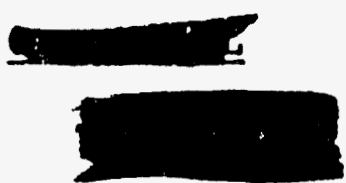



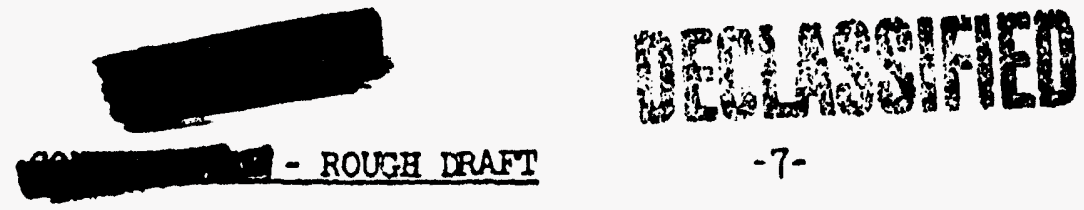

$-7-$

oxalate at 250 - $350 \mathrm{C}$ was found to chlorinate more realily than $1 f$ calcined at 400 - 500 C. For the latter, 1rcreased chlorination temperature was helpful. A test was male on oxdde calcined at $900 \mathrm{C}$. About 30 grams of thls was chlorineted in four bours by phosgene at 500 - 550 C. A emall sample of oxtde which rad been 1 gaited in the carbon arc of a spectrograph was also success nully chlorinated in four hours at about $525 \mathrm{C}$. The se experiments indicate that chlorination may be userul on recovery of 1 gontel wastes.

Normally there was no evidence of oxychloride in the products of phosgene and carbon tetrachloride chlorinat1ons. Some batch chlorinat1ons whlch were 1nterrupted indicated 11ttle, if any, oxychlor1de between the dioxide and the trichlorids with elther of these two reagents. Dellberate attempts to proluce oxychloride (PuOCI) w1th water vapor and a mialmum of carbon tetrachloride indlcated 11ttle or no oxychloride was formed. When scuse oxychlorlde was obtained (discussed later), some 10 grams of 1 were treated w1th phosgene at 470 - $500 \mathrm{C}$ for nearly four hours. The analytiral laboratory reported complete conversion of the PuCCl to PuCl3. These observas t1ons indscate that direct formation of trichloride is the most significant reaction of phosgene and carbon tetrachlorije. Any amounts of plutonium oxychlorlde formed are readily converted to tricklor 1de by phosgene.

Carbon monoxide and chlorlne in equimolar mixtures were used on 1.0-gram batches of oxide. On one there was no apparent chlorination in three hours at 450 - $500 \mathrm{C}$. Two more hours at 525 - $550 \mathrm{C}$ produced a dark, grey-green cake. A seconl batch was chlorinated at 500 - 550 C for almoet three hours. Chlorination was camplete on both. These gases required a hlgher temperature than is necessary with phosgene.

Hydrogen and hydrogen chlorfde, which were used in amall-8cale plutonlum chlorination work, $(1)(6)$ were trled here only once. A batch of 117 grams of plutonlum oxide was treated with mixed hydrogen and hydrogen chloride at $450 \mathrm{C}$ for three and one-half hours without success; then at 540 - $570 \mathrm{C}$ ior 14 bours, which removed all visible color of oxide. Laboratory analysis sbowed incomplete chlorination. X-ray dffraction study Indscated much of the product was plutonlum oxychlor1de, PuOCl. Further work w1th the hydrogenhydrogen chlorlite reagents was discontinued due to the slow chlorination rate, incomplete chlorination, and the lmediate hazard of hydrogen explosions.

\section{Large Batch Chlorinat1ons}

Carbon tetrachlorlde having worked well on a small acale, was used for 300-gram batches before the small batch tests of phosgene were completed. It was whlle producias trichloride for reduction testu that the two reagents were more filly comparsi.

\section{DECLASSIFIED}

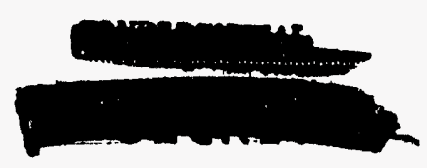


A Pyrex powder vessel and a pot rurnace (F1gure 1) vere loaded with 300 grams or more of plutonfum dioxide. An excess of chlorloating agent passed through the powder, the support1ng rit, and then to the t.ap and the caust1c ocrubbere. Problems with pluged exhaust lines were camon with the large batches. Cenerally this was due to carbonate salt formation as the caustic approached neutrality.

With carbon tetrachloride, the plugging was also caused by collections of unidentified white solids in the trap and in the f1rst scrubber. These were not water-soluble. When the exchaust gases from the chlorinator were scrubbed once with caustic, then passed through a cold trap at $-50 \mathrm{C}$, several 11quid fractions were formed. These were found to have bolling polnts of $8,16-18$, $22,27-29,74-75 \mathrm{C}$, and h1gher. One of the higher bolling components was a yellow v18cous fluid and the second a wax-like 111m.

Ilterature on various uses of heated carbon tetrachloride as a chlorinating agent indicate by-products of chlor1ns, phosgern. $\mathrm{C}_{6} \mathrm{C}_{6}, \mathrm{C}_{2} \mathrm{Cl}_{4}, \mathrm{C}_{2} \mathrm{Cl}_{6}, \mathrm{CO}_{2}, \mathrm{CO}$, and possibly others. A means for filtering and disposing of such a varlety of by-products from a large-scale unit presented an extensive problem.

The few sollds forming in the off-gas 11 es from phosgene chlorination were mostly water-soluble.

With both reagents, a problem of temperature control was experlenced. In batches containing 300 grams or more of plutonium, about half resulted in exothermic reactions. The temperature rise started at $420 \mathrm{C}$. The temperature was partially controlled by interrupting the chlorinating reagent and turning off the electric furnace. About 10 percent of the batches resulted in excessive temperature $(>600 \mathrm{C})$, and the loss of a Pyrex vessel. It was not determined whether or not the observed beat rise was due to further calcination of the oxide prepared at $350 \mathrm{C}$.

The temperature of phosgene was given more study on 300-Eram batches. Phosgene chlorinated the oxtde slowly at $300-400 \mathrm{C}$. At 400 - $450 \mathrm{C}$, the reaction rate was $\mathrm{Bood}$, and 1 it contlaued to

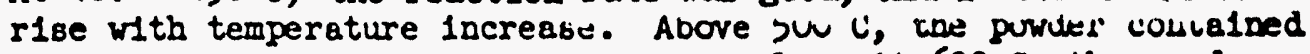
more lumps and larger and darker crystals. At $600 \mathrm{C}$, the powder sintered Into a hard calse. The reaction rate with phosgene through the range of 300 - $540 \mathrm{C}$ 1s equivalent to the rate with carbon tetrachloride at 50 - 100 degrees higher. This 18 eapecially signiflcant in the corrosion rates of metals. The excess of reagent required was roughly the same for both chemicals.

To sumarize a ccomparison of the two reagents, phosgede permitted a cholce of lower chlorinating temperature or blgher reaction rate. By-products in the phoogene chlorination exhaus t were fewer

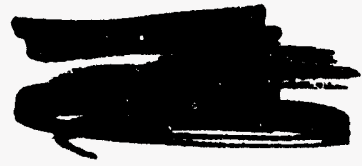




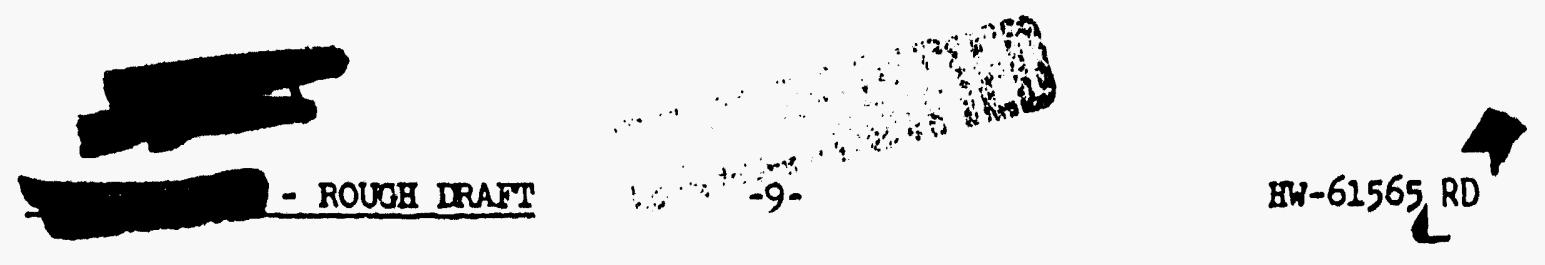

and less Ilkely to laterfere with gas riltering. The cinolce was phosgene, if it could be used with nafety.

The safe uns of phosgene has beers demonstrated on this program for well over a year. Phosgene safety 1s decusbed under VII, Append1x.

Chlorinations of plutonium dloxide with phosgene vere scaled up to a one-k1logram batch s1ze, the largest batch contalniag $1.1 \mathrm{~kg}$ of plutonium. The chlorination of kllogram-bstcbes required 12 . 20 hours at temperatures of 430 - $550 \mathrm{C}$. The product was dark and caked at the upper region of these temperatures, but was 11ght and Iree-flowling if the temperature was on the low s1de. The chlorinat1on was slowest at the bottom and center of the tatchss dur to sbrinkage of the powder away from the vessel walla, resilting in channeling. If the chlorinations were interrupted, stirring of the powder helped eliminate tha gas channeling.

Experlence showed that complete chlorlnation required a two-fold excess of phosgene. Th1s 18, ore mole of PuO2 required s1x moles of $\mathrm{COCl}_{2}$. A flow sheet, Floure 2, Blves material balances for th1s process. The flow sheet includes the caust1c required to neutralize all exhaust gasss. Caust1c scrubbers were used in th18 program, but as 18 discussed later, gas dilution 18 recomended.

The feasibility of batch chlorination was vell demonotrated with 59 batches of varlous $812 e s$ which contsibed pearly 25 kllograms of plutonium. A 400-gram batch olze proved most convenlent for an e1ght-hour operation. The plutonlum trichlor1se produced was sat1sfactory in subsequent reduct10ns, except for recognized off-standard preparations. The analyses of oamples indscated average chlorination was 97.3 percent complete.

\section{Cont1nuous_Chlor 1nator_-_Pyrex_REactor}

A small continuous chlorlator was used to determine the feas1bllity of chlorinating plutonium dioxide in a cont1mous system. An electric vibrator moved powder down an inclined one-1nch Pyrex tube passing through two 12-1nch furnaces (F1gure 3). An Eagle timer and a variac controlled the intermittent operation of the vibrator. Phosgene gas was mitered and pasaed counter-current to the powder. Plutonlum dioxide powder was fed by a Teflon rotary valve turned by a reduction gear motor. In18, in turn, was operated intermittently by a timer and a variac.

Typ1cal operat1ns cond1tions were as follows:

Temperuture (hottest polnt in chlorinator): $500 \mathrm{C}$. Furnace length: 24" total, $18-20 "$ at $450 \mathrm{C}$ or above. Residence time in furnaces: $45 \pm 10$ minutes.

Phosgene flow: 1.5 moles per hoür, or 6 moled per mole $\mathrm{PuO}_{2}$.

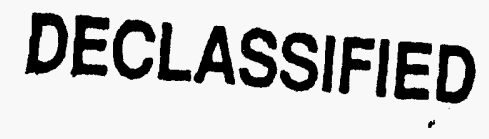




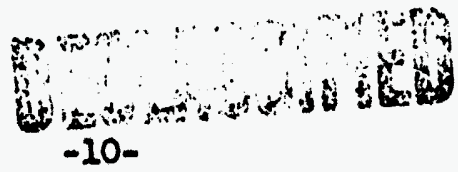

Powder bed depth: $1 / 4-3 / 8^{\prime \prime}$.

Tube slope: 2 degrees.

Vaculm applied to chlorinator: $1+1 / 2^{\prime \prime} \mathrm{H}_{2} \mathrm{O}$.

Vibrator operation: 1 second on, 60 seconds off, var1ac 120.

Oxide feed: Set at $1 / 2$ revolution per cycle.

$1 / 2$ revolution $=2 \mathrm{~B} \mathrm{Pu}$.

Timer: 2 minute cycle. Adjust only the off-time

for rate change.

Average rate: $57 \mathrm{~B} \mathrm{Pu} / \mathrm{hr}$ for 30 hours.

The glass permitted visual observation of the chlorination progress. For example, once 1t was observed that chlorination appeared incompleite on powdse halfway through the furnaces. Increasing the temperature by 30 degrees resulted in a viatble change in 10 minutess

A1r leakage 1nto the chlorinator was a serlous obstacle unt1l discovered and corrected. Oxygen 18 incompat1ble with the chlorination reaction.

When rate or temperature tests ylelded brownlsh-colored powder, th1s was recycled to complete the chlorination.

The Rlass reactor was operated under severe vibrat1on and at temperatures up to $550 \mathrm{C}$. At this temperature the tube bent olightly under straln but wa rebeated and stralghtened. One tube was broken by a bump from a wrench after 275 hours of operating time. The replacement tube has not yet recelved that much usage.

Sollds collected on the surface of the cold area of the reactor tube and in the off-gas ine. They ranged in color from ton to rery dark brown as a function of temperature. These proved to contain volatile chlorldes which will be discussed later in the section on exhaust gas filtering.

The formation of lumps of chloride powder was a frequent occurrence. These were usually broken into small lumpe by the action of the vibrator. Remalning lumpe whlch entered the recelving jar were usually powdered by shaklng the bearly-full bottle. Same lumps, being hard, entered the reduction operation in chunks up to marbles1ze, but gave no reduction problem. These lumps rarely showed 10complete chlorination on the 1nside. The lumpe frequently interferred w1th the powder flow, but rarely plusged the resctor. Iump formation orlginated only at the entrance to the furnace where chlorlnation began (temperature about $300-400 \mathrm{c}$ ). Most of the plutonlum tr1chloride was a free-flowling powder, 11ght-greenlab-blue in color.

Operation of this Pyrex chlorinator to date has produced 6.2 k1lograms (as plutonium) of sat1sfactory plutonlum trichloride.
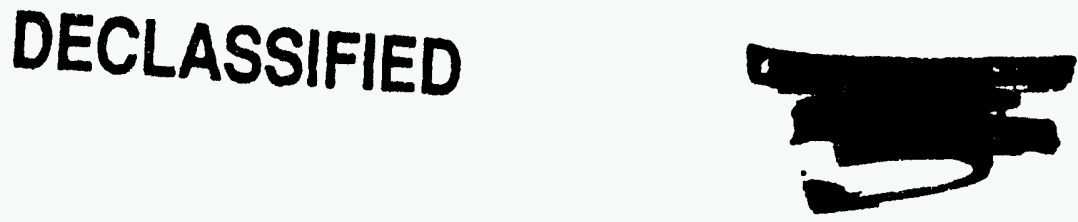


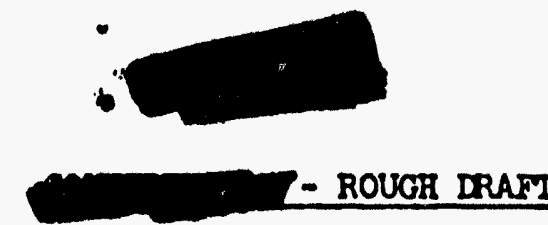

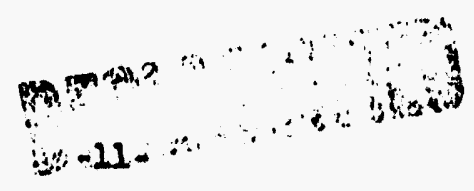

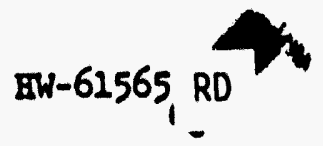

\section{Cont1므ous_Chlorinator_-_Demongtrat1on_Reactor}

A larger continuous chlorinator vas prepared to surther demon-trate the chlorination process. Ints undt, known as the demonstration chlorinator, 18 plctured in Figures 4,5 , and 6.

The Hastelloy B chlorination tube has an oval cross-section. Ins1de dmensions are 1-1/4" $\times 2-1 / 4 "$, having 1 " of Nat aurface and $3 / 4^{\prime \prime}$ radius bends. Total length $1849^{\prime \prime}--32^{\prime \prime}$ of 1 t Inside the two hurnaces an end plates. The temperature 18 not unsform through the rurnaces. Flgure 7 Indicates a typlcal temperature graph of the unst wh1ch shows about 21 " at chlorinntion temperature of $450 \mathrm{C}$ or above. Heating cable along the upper exposed tube (not shown) provided additional temperature control. Chramel-alumel thermocouples vere located to record the hottest points in the rurnaces, usuarly $525+25$ $C_{0}$ The corresponding hottest maximum chlorination tube temperatures w. $500 \pm 25 ?$.

Powder was recelved and delivered through FVC ball ralves (maxdmm observed temperature $60 \mathrm{C}$ ). A black Te Flon bellows (M1gure 6) (maximum observed temperature $160 \mathrm{C}$ ) 180lated the receiving valve from the vibration used to move the powder through the tube. Inert gas bleeding 1nto the system between two valves prevented the phosgene gas fran work1ng back 1nto the calciner which provided the oxide powder. Phosgene gas, supplied rom outs1de the bullding, was metered counter-current to powder flow and out through a ceramic primary filter (F1gure 6), through a cooling trap and a secondary filter into a scrubber contalning caust1c. The top of the hood was provided w1th a water cooling jacket. Uncooled parts of the top reached a temperature of $52 \mathrm{C}$. Dry a1r slyplied at about two cuble feet per minute kept the hood at $-20 \mathrm{C}$ dew polnt or better. Mater1al entrance and ext were by plast1c bas procedures.

There were several operating problems v1th this equipment. When the phosgene passed the control valve, the cooling ran expansion was oufficlent to 11 quify the phosgene. Beating the valve to 110 $120 \mathrm{C}$ corrected this problem.

Off-gas fliters were or 1 ginally ceramic flagers supported from one end by a ceramic flasge or bead (F1gure 6). Breakage of these caused several delays unt1l the ceramic I1ngers vere comvarted to cyl1nders and given metall1c support through the center (F1gure 8).

Fllter bous1ngs were or1ginally Pyrex glass pipe (F1gures 5 and 6). After a few of these were broken, a factory-made "Double Tough" Pyrex Tee was successfully subst1tuted. Subsequently, a Bastelloy C housing was fabricated. Another themocouple and $a$ beating cable were added to malntain r1lter temperature above $350 \mathrm{C}$.

Powder How through the reactor tube wao errat1c. W1th every change of fllter housing, the rosonance of the tube changed and re-
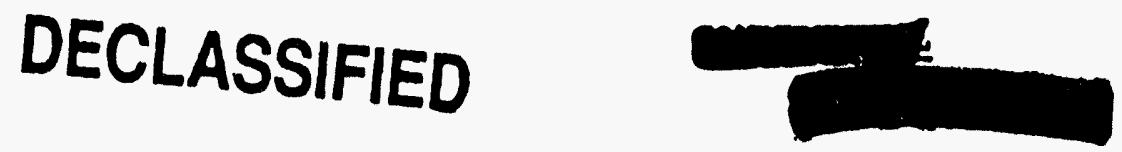


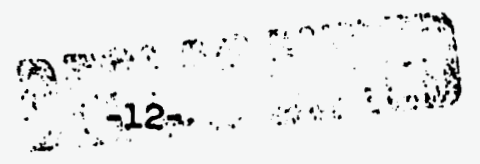

whred hew vibration control settings to more the porter.

Dowder lumps sometimes plugged the exde from the chlorinator. - plunger To break the lumps was installed. Lumps vere most troublescose when a shutdown Interrupted the progress and agitation of the powdero

Ae this writing, $13.5 \mathrm{~kg}$ of plutonfun have been converted from oxide Co chloride in the demonstration chlorinator.

optimum operating conditions found to date are as follows:

Furnace temperature: ic $525 \mathrm{C}$; tube maxtmum $500 \mathrm{C}$. F1ltex temperature: $350-400 \mathrm{C}$.

Preffurnace temperature: $350 \mathrm{C}-40000$

Phosgene flow: 6 moles per mole of $\mathrm{PuO}_{2}$.

Powder flow: 0.8 moles, or $200 \mathrm{~g}$ Pu, per hour.

Powder bed depth: $1 / 4-3 / 8$ "

Powder residence t1me: $45 \mathrm{~min}$. In furnace, one hour total.

Vibration: $10 \mathrm{sec}$. on, $10 \mathrm{sec}$. off. Intensity setting 80 .

Chlorinator slope: 4 degrees.

Chlorinator vacuum: 1 - 10" of water.

The flow sheet showa for batcl phosgene chlorinations applies to the continuous operation (F1gure 2).

Some of the chlorination rates observed to date are found in Table I.

\section{Mater1묘요 요_Construct1on}

Chlorination tubes of Pyrex and of Hastelloy B bave been used successfully at temperatures of $500+25 \mathrm{C}$. According to recent tests of W. I. Walker (to be publ1shed), metall1c chlorination tubes may be of Bastelloy C, nickel, Chlorimet-2, N1-0-Ne1, or Bastelloy B. All show nearly one mil per month corrosion in phosgene at $500 \mathrm{C}$ (Table II). Any Increase in temperature causes a sharp increase in the corrosion rate.

Ceranic filters show no deterioration in the exbaust gases. A ceramic cylinder held by metallic eupports 18 durable and inexpensive. Presumably metallic frits would suffice, but these were not tested due to the cost of such filters.

The filter housing and filter supports (mintmum temperature 350 400 C) must be of Hastelloy B or C or equivalent where in contact with the hot gases. Beyond the rilter where powders cannot return to the chlorinator, corrosion rates of materials are less important. Where geses cool fram $350 \mathrm{C}$ to rocm temperature in a plpe (or possibly a cold trap), condensing metallic chlor13es will likely plug the plpe unless these sol1ds are removed. At about $100 \mathrm{C}$ were water vapor
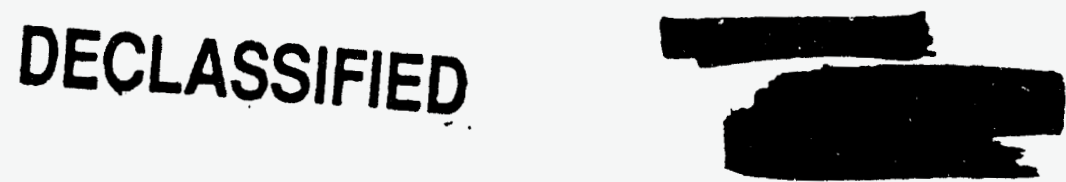


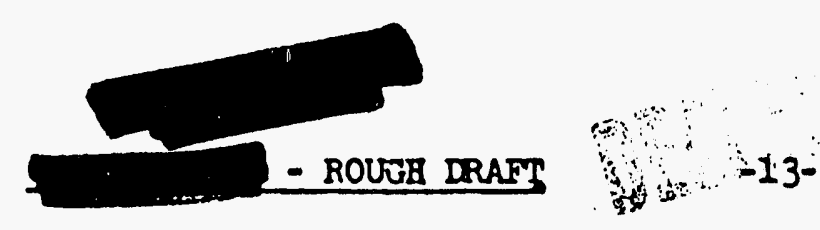

$8 W-61565$ RD

TABLE I

PUO2 CHLORINATFON RATES - DEMOISTRATION CELURIMATOR

TABTE II

CORROSION OF MATIRTALS IN PBOSGENE(1)(2) Corrosion Rates In M1ls Penetration Per Month

\begin{tabular}{|c|c|c|c|c|}
\hline \multirow[b]{2}{*}{ Material } & \multicolumn{3}{|c|}{ Furnace } & \multirow{2}{*}{$\frac{\text { Exhaust Gas }}{90-100 \mathrm{C}}$} \\
\hline & $400 \mathrm{C}$ & $500 \mathrm{C}$ & $600 \mathrm{c}$ & \\
\hline $\begin{array}{l}\text { Bastelloy B } \\
\text { Bastelloy C }\end{array}$ & $\begin{array}{l}0.02 \\
0.02\end{array}$ & $\begin{array}{l}0.9 \\
0.6\end{array}$ & $\begin{array}{l}7.2 \\
6.1\end{array}$ & $\begin{array}{l}7.1 \\
9.0\end{array}$ \\
\hline N1ckel & $\ldots$ & 0.6 & 4.4 & نี \\
\hline Cblor Imet-2 & $\cdots$ & 0.8 & 5.6 & 11 \\
\hline N1-0-Ne1 & $\cdots$ & 0.9 & 12 & 19 \\
\hline
\end{tabular}

(1) Phosgene plus 50 percent water-saturs.ted a1r, flowlng at 211 ters/hour.

(2) Unpublished data by W. L. Walker, Blo. 

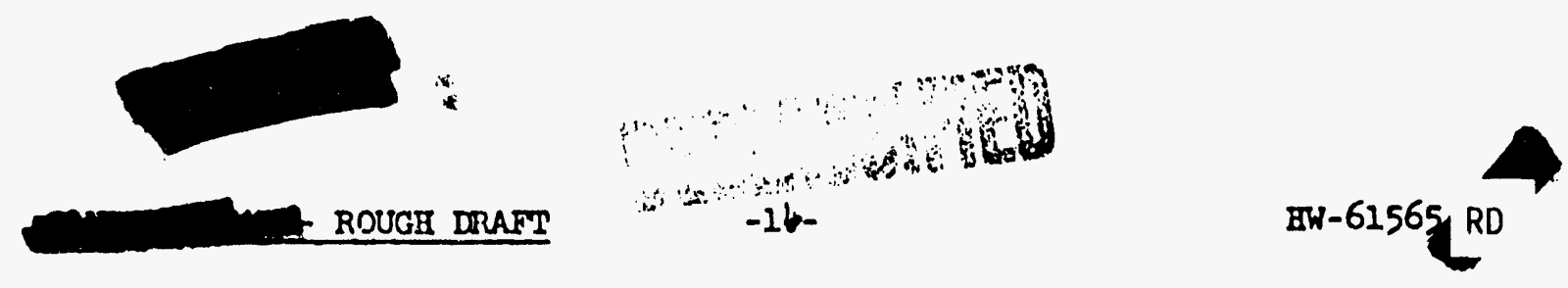

from molst powder may condense, tests Indlcate increased corrosion (Table II). The most simple design could be replaceable stainless plpe where the gases cool. For the cold section of the off-gas IIne, rigid PVC or other plastic pipe 18 recomended.

Phosgene 18 supplied in black Iron cylinders. The manufacturer recomends and sells an fnexpensive control valve and cylinder adaptor which has copper tubing. Copper, 1ron, monel, and stalnless steel are sultable as supply plpes. No leakage can be tolerated.

Many plast1c8, such as Teflon, rigld PVC, polyethylene, Saran, and Kel-F, are sultable for use with phosgene. When plestic1zers are present as in flexible tubing of PVC or PVA ("Tygon", "Nalgon". etc.) or In plast1c bags such as Bakel1te "Krene". the phosgene reacts with the plasticizer causing discoloration and deterioration. Polyethylene tubing and bags can he used in preference to the "Tygon" or "Krene".

Gum rubber, Neoprene, s1l1cone rubber, and synthet1c rubbers generally are unreliable unless the formulation has been tested and found sat1sfactory. Indeed, some have proven very sultable; partic* ularly in dry atmosphere where the plestic1zers, too, are less trouble same.

The preceding paragraphs apply to gaskets just as to tubing and equipment parts. Var1ous asbestos gaskets have proven userll with phosgene on the hot equipment. An asbestos gasket which has absorbed phosgene may swell and become useless if exposed to water or molst a.r.

Hoods may be of 304L stainless steel, prov1ding a ary atmoaphere is malitalned. The anhydrous plutonlum trichlorlae 18 non-currosive; but at humidit1es above dew polnt $-20 \mathrm{C}$, It absorbs water and becomes corrosive. At dew polnt $+15 \mathrm{C}$, the test samples showed significant corrosion. Where phosgene leakage in a hood 18 possible, the dry atmosphere (dew point - $20 \mathrm{C}$ or better) 18 of major importance. Should appreciable phosgene escape into a hood with molbt alr, the phosgene and molsture form a corrosive film of hydrochloric acid on the exposed surfaces.

The objects f1rst attacked by phosgene in a hood where the bum1d1ty was allowed to r1Be, were those of brass or $21 n c$. The brass parts of a balance, an electric cover plate, and laboratory clampo became wet and corroded. Tools sprayed with Krylon obowed reaction with phosgene in alr before "unprotected" tools were attacked.

B. Chlor1nation Exhaust Gas D1sposal

1. F1ltering

The primary purpose of flitering was to prevent 108 s of plutonlum
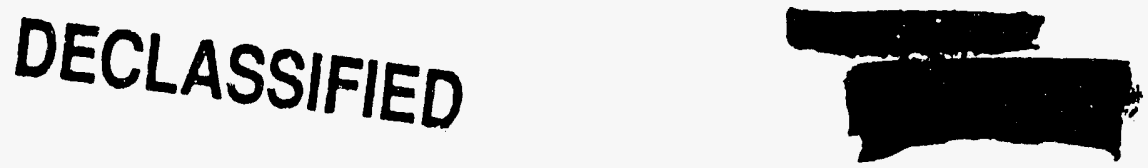


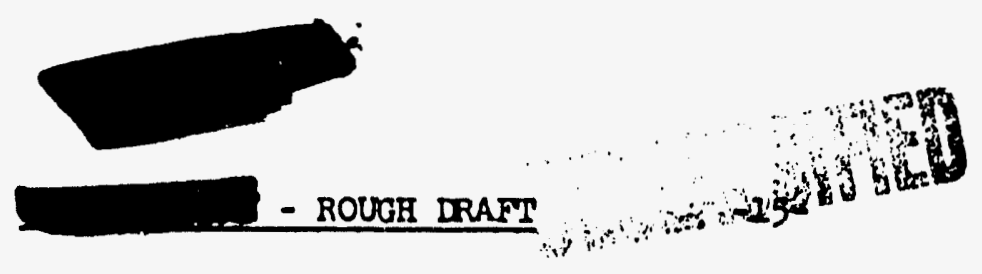

BW-6156G RD

v1a the off-gas stream. Some filters improvised with glass wool and bottles were useful in preliminary work or as secondary filters. For primary ifftera, sane comercially-avallable ceramics were teited by Rey.(18)

The fliter housing and ceraulc finger filter shown in Flgures 5 and 6 were unsatisfactory due to breakage. The Pyrex plpe housing shown was replaced by a factory-made "Double Tough" Tee which proved durable. The beaded or Flanged ends on the finger filters usually broke when t1ghtened 1nto place. Th1s was probably due to the necessity of hlgh tempernture asbestos gaskets, wh1ch differ greatly from the soft rubber gaskets supplied. When the ceramic flagers were cut Into cylinders and given a Hastelloy $C$ support (F1gure 8), the filter breakage was eliminated.

Ceramic filters were used flrst at low temperature, $50 \mathrm{C}$ or less. A Selas XF filter plugzed after 23 hours' use, and a Selas XFF lasted only 13 hours at low temperature.

The plugging was not due to bulldup of dust on the filter, but to condensation of metallic chlorides volat1lized out of the reactor. The oxide feed contained slgnificant amounts of aluminum and Iron at the time of these tests. The approximate bolling polnts of most chlor liss and carbonyls which could pass a heated fllter as vapor are as follows:

\begin{tabular}{|c|c|c|c|}
\hline $\begin{array}{l}\mathrm{AlCl}_{3} \\
\mathrm{BCl}_{3} \\
\mathrm{FeCl}_{3} \\
\mathrm{MoCl}_{4} \\
\mathrm{MoCl} 5 \\
\mathrm{WCl}_{5} 5 \\
\mathrm{WCl}^{6} 6\end{array}$ & $\begin{array}{rl}183 & c \\
12.5 & c \\
319 & c \\
312 & c \\
268 & c \\
276 & c \\
337 & c\end{array}$ & - & $\begin{array}{l}\mathrm{SICl}_{4} \\
\mathrm{CrCl}_{4} \\
\mathrm{Fe}(\mathrm{CO})_{5} 5 \\
\mathrm{NI}(\mathrm{CO})_{4} \\
\mathrm{SnCl}_{4} \\
\mathrm{TICl}_{4} \\
\mathrm{2rCl}_{4}\end{array}$ \\
\hline
\end{tabular}

To permit aluminum chloride or ferric chloride to pass through the filter, a beating cable was wrapped around a Pyrex "Ire" filter housing to provide a temperature of $350-400 \mathrm{C}$. Thereafter, a new Selas XF filter was used at this temperature for 58 hours before it was removed to test other filters and filter housings. Vibration had not damaged the f1lter. The dust and volat1le chlorides which had passed this filter in the last 42 hours of operation contalned 12.4 percent plutonium. A generous estimate of the conjensate and dust welght indicated that less than 0.5 gram of plutonlum bad passed the filter as dust or vapor. Th1s is partlally recoverable from a oultable cold trap following the filter.

The filter sample referred to above was also analyzed by opectrograph. Major const1tuents were 1ron and phosphorus (no explanation). Present 10 strons amounts were boron, molybdenum, cluranium, and zinc. In lesser concentrations were aluminum, alckel, o1licon, and t1tanium. Aluminum content of the oxide feed was less

○

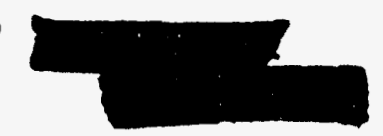


than 10 ppr at the time of thede tests. Rey $(18)$ reparte.l success with back-Mushing. Th1s has not been sueflciently evaluated with plutinium dusts because chlorinator vibration removed any cake over $1 / 8$ inch in thicknesses fran the fliters and droppes it back 1nto the chlorinator.

\section{Exhaust Gas Compusit1on}

Ges analyses work by Lust(19) during operation of the small cont1nuous chlorinator indicated the followlng major const1turents in the off-gases when operating with a four-fold excess of phosgene:

\section{Volume Percent}

$\begin{array}{lc}\mathrm{COCl}_{2} & 7-57 \\ \mathrm{CO}_{2} & 20-50 \\ \mathrm{CJ}^{2} & 10-20 \\ \mathrm{Cl}_{2} & 7-12 \\ \mathrm{HC}+ & 7-9\end{array}$

The wide varialtions in the phosgene and carbon dioxlds values are normal because they vary with the degree of phosgere ut1l1zation at the time of sampling.

The carbon monoxide and same of the chlorine are protucts of phosgene dissoclation. The hydrogen chloride 18 frcx phosgene hydrolyo1s due to residual mo1sture in the plutonium dioxide. Conoumption of caustic in the ocrubber is effected little by those slide reactions of the phosgene.

\section{Exheust G:B Neutral1zat1on}

It was necessary to neutral1ze corrosive gases from the chlorinator exhaust to protect the hood exhaust plping. These gases were abeorked in caust1c.

The scrubber system (F1gure 9) used for gases from the demonstration chlorinator was designed to laclude some recomendations of key $(20)$. The upper portion was operated as a gas phase column and the lower, large dlameter section was fllled w1th the sodium hydroxide. Caust1c reclrculated from a 25-gallon tank, down the culumn, and back to the tank. Experlence with th1s system proved that more operator effort went to the scrubber than to the chiorinator.

Off-gas treatment by a caust1c scrubber neutral1zeo phosgene, hydrogen chloride (from molsture and phosgene), carbon dioxide, and chlor Ine. Carbon monoxiae and nltrogen (alr leakags) bubble through unchanged. An economic 1088 is experienced in the unnecessary use of caust1c by the carbon dinxide, whlch need not be noutral1zed. Ihe chemlcal reactions are the followlng:

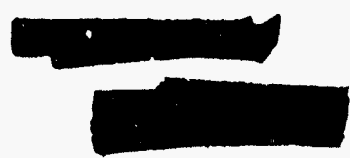




$$
\begin{aligned}
& \longrightarrow
\end{aligned}
$$

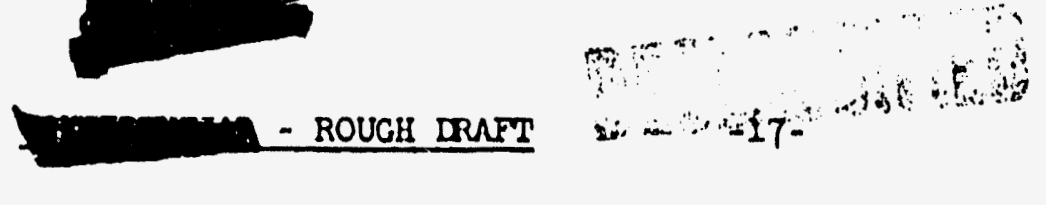

$$
\begin{aligned}
& \mathrm{COCl}_{2}+3 \mathrm{NaOH} \longrightarrow \mathrm{NaHCO}_{3}+2 \mathrm{NaCl}+\mathrm{I}_{2} \mathrm{O} \\
& \mathrm{BCl}+\mathrm{NaOH} \longrightarrow \mathrm{NaCl}+\mathrm{I}_{2} \mathrm{O} \\
& \mathrm{CO}_{2}+\mathrm{NaOH} \longrightarrow \mathrm{NaHCO}_{3} \\
& \mathrm{Cl}_{2}+\mathrm{ZNaOH} \rightarrow \mathrm{NaCl}+\mathrm{NaOCl}+\mathrm{H}_{2} \mathrm{O}
\end{aligned}
$$

As the neutralization procended, the caustic normallty diminisbed from o1x to about one, below which point carbonate precipltation threatened to plug the systism. The chemical reaction warmed the system to $50-60 \mathrm{c}$.

\section{Exhaust Gas D11ut1므}

The most sat1:factory diaposal uf corrosive gases from chlorination 1s by dilution. After the gases are filtered, and cooled to remove condensates, it 18 feasible to paso them through noncorrosive plpe ouch as rig1d PVC direct to the stack. Whero adequate dilution 18 avuliable, the use of a caust1c scrubber is thereby arolded.

\section{Recovery_ot Phosgene}

Several trials were made to recover the excess phosgene leaving the chlorinator. Because phosgene 11quifles at about $8 \mathrm{C}$, 1t is easily trapped in a bath of dry lce and alcohol, or one of 1 ce and brine. Reuse of such recovered phosgene was satisfactory in oubsequent chlorination, but was an 1nconvenfence in the laboratory. The economics and safety of phosigene recovery, rather than any process difficulties, should detismine the feasibility of sald recovery.

\section{Character1st1cs of Plutonfum Ir 1chlor1do}

\section{Stab111ty}

Anhydrous plutonium trichlor1do is stable for an Inderinlte period at roan temperature in a dry or Inert atmosphere. Ox1dation to dloxide appears after about four days in no1st roam alr or 40 - 50 percent relative hunidity. At $100-150 \mathrm{C}$ in air (bumidrty unknown), the powder surface oxidized overnight. Oxidation proceeds rapidly in air at $400 \mathrm{C}$ or bleher.

Dry plutonium trichloride wh1cb has partially oxidlzed may bo rechlorlnated w1th phosgere. If water of hydration 18 preoent, the temperature should be lalsed ol rwiy whlle oweoping the powder w1th the dry gas. Tha powdr: will molit and cake 11 the melting polat $(94-96 \mathrm{C})$ of $\mathrm{PuCl}_{3} \mathrm{OH}_{20} \mathrm{O}$ is reached bofore th1s water 16 removed. vacuum drying 10 uleo fonsible.

\section{DECLASSIFIED}

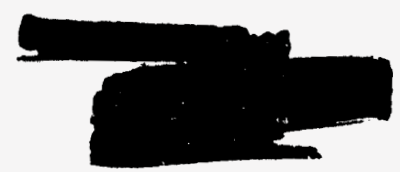




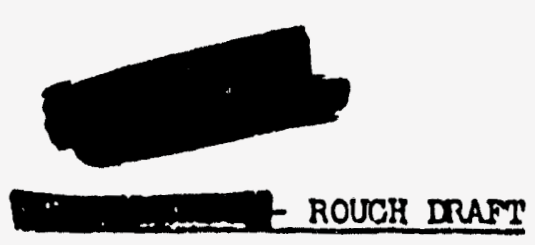

2. Color

The color of anhydrous plutonfun trichloride, areenlob-blus, 18 an excellent 1ndscator for the abnence of ibe creen-olive dloxids. As 21ttle as oxe or two pernent dloxtde 1s v1ounily detectable, enpocially as a sine tramber iust sottiling on the top of the powder after sbaking the contelner. When five percent or more diexdde is present, the Ereenish-blue chloride color 1s maked almost completely. Incomplete chlorination is indicated by any brownish appearance to powder or lumps. Color detection of oxychloride is not rellable because its color is olmilar to the trichlor 1de.

The chlorination tempiratiure (and probably other variables) Influence the powder color. Chioriantion at $400 \mathrm{C}$ results in a light blue-Ereen (ahost erey) powder. Illgher temperatures up to fro C produce larger and darker crystals. sintering 10 apparent arter $650 \mathrm{C}$ 1s rached. Upon bydration to $\mathrm{PuCl}_{3} \cdot 6 \mathrm{H}_{2} \mathrm{O}$, the color becomes a bright, blue.

\section{3. ㅁydration}

Anhydrous plutonium trichlorido is hyeroscoplc, so must be bupt in a debumidified atmorphero or sealed contalner. A ccrew cap elass Jar w1th waxed paper or polyothylene gasket in the cap 1s not oultablo protection at 40 percent relative bumldity. Replacing the paper gasket with TeRon, Neopmone, or other mo1sturo-1mporvious material will sursice 15 tlehtly closed. In the laboratory, a desiccator contalining "Dr1er1:0" (dew point -62 c) proved corvenient. $\Lambda$ dehumidirled atmosinere should be dew polnt $-20 \mathrm{C}$ or better for Indorinite storage.

Thin Ilim of the tricbloride powder are doliquescent (form wet mudiles) at relative bumidites Ereater than 40 percent. De11queocence wes observed after 20 minutoe at 52 persent relative hunde1ty.

When trichloride powder in glaso jars 10 exposod to humid alf, the proeress of hydratina may lo noted by the color change srom blue-green to bright bluv; 1.e., from anhydrous to hexahydrate. Intermediate hydrat1on etepo pre not ovidont, but may be formed under controlled cond1tions. (21)(22) Hydration lows, as a barrler of hoxahydrate protects the anhydrous salt from the molot air.

Ilydration ratos aro larpely influenced by the phyalcal arrangements of the apparatus. Dlameters of the exposed powdar surfaces primarlly control the dirferences in hydration rates. A nurrow, deop container would reduce tho hydration rato below that of un equal welght of powser in a wito, muliow contalnar. Contalner. wero choben to wo mlnialureo of powder pans. The inalda diasoter

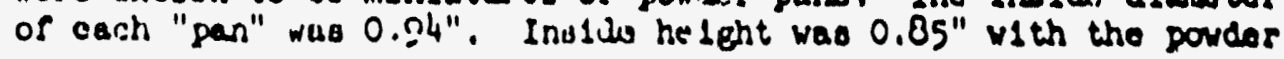
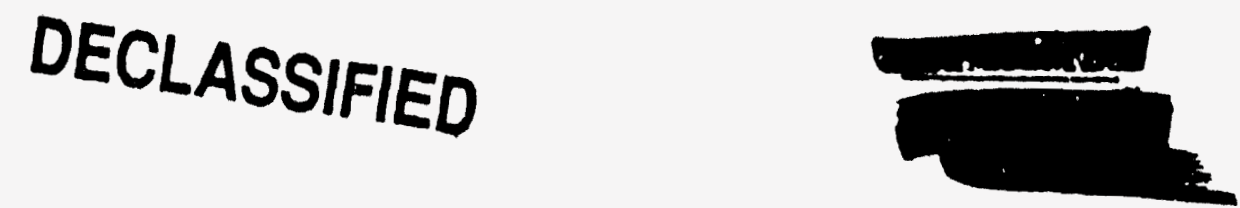


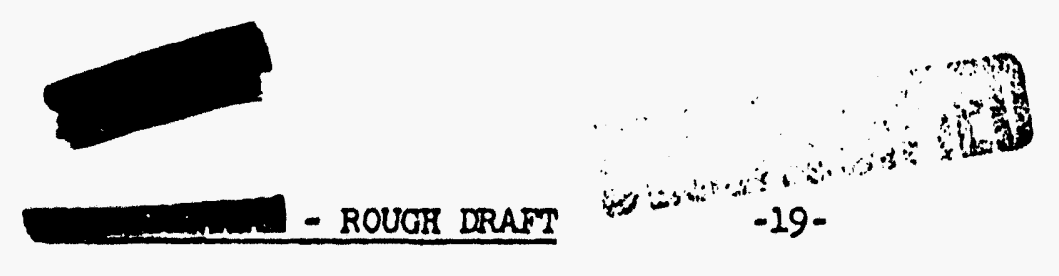

added unt1l 0.75 " deep. Powder in these "pans" was expesed to controlled atmosphares of dew points $-28,-20,-18,-15,-13,-5$, $+5,+13$, and +15 degrees cent1erade. These atmospheres were provided in olntment-jar deslccaturs contalning oulnuric ac1d of known specif1c gravity. The relationsh1p of dew polnt to sulfuric ac1d apeciflc eravity (23) is glven for 20 cent1grade. The temperature was 20 - $23 \mathrm{C}$ durlas the test per1od, but all values are besed on the $20 \mathrm{C}$ temperature.

Each port1or of chlorlde porder orlginally welghed $17 \pm 2$ Erams. Welghing to flve signiflcant flgures was done in a dry atmosphere at 1ntervals. Powder exposed to alr of dew polnt $-28 \mathrm{C}$ and dow point $-20 \mathrm{C}$ showed no we1ght gain. At dew polnt $-18 \mathrm{C}$, the welght gain, If any, was less than 0.01 percent in a thousand hours. At $-15 \mathrm{C}$ dew point, the gain was about 0.6 peicent in 650 hours. At $-13 \mathrm{C}$ dew polnt, the gain was 0.5 percent in 200 bours. Powder contalning 0.5 percent water has been ouccesenully reduced. Addit1onal data may be read from Floure 10.

\section{Other Craracter1st1cB}

Anhydrous plutonsum trichloride has a melting polnt of $763 \mathrm{C}$ and a bolling point of $1770 \mathrm{C}$, although decomposition begins below $1500 \mathrm{C}$. Ite vapor pressure $180.012 \mathrm{mb}$ HB at $750 \mathrm{C}$.

Two rarticle-s1ze observations were made on a Flober sub-s1eve s1zer. Average particle slzes were reported as 4.1 for a largebetch chlorination with phosgene at $500 \mathrm{C}$, and 6.1 micron for the Pyrex cont1nuous-chlorinator using phosgene at $460 \mathrm{C}$.

Zacharlasen(21) has reported that the anhydrous salt has a hexagonal cryotal having a calculated crystal donsity of 5.70 per cublc centimeter.

Bulk density of the powder 1s usually $2.6+0.4$ ram per cuble centioeter. Observations r: bulk density are shown in Table III.

A somple of anhydrous plutonfum trichlorido was subaltted to Hanford Laboratorles Operation for the measurement of peutron emlsB10n rate. The reported anower (24) was tabulated in compar1son with the tetrafluoride and plutonfum metal as follows:

\begin{tabular}{|c|c|c|c|}
\hline \multirow[b]{2}{*}{ Compound } & \multicolumn{2}{|c|}{ Endso1on Rate } & \multirow{2}{*}{$\begin{array}{c}\text { Average } \\
\text { Noutron } \\
\text { Energy, MOU }\end{array}$} \\
\hline & $\begin{array}{l}n / \mathrm{Bec} / \mathrm{B} \text { of } \\
\text { Compound }\end{array}$ & $\begin{array}{c}\mathrm{n} / \mathrm{sec} / \mathrm{s} \\
\text { or Pu }\end{array}$ & \\
\hline $\begin{array}{l}\text { Pu } \\
\text { Purt } \\
\text { PuCl }_{3}\end{array}$ & $\begin{array}{r}96 \\
6350 \\
96\end{array}$ & $\begin{array}{r}96 \\
8870 \\
138\end{array}$ & ca $\begin{array}{l}1.9 \\
1.4\end{array}$ \\
\hline
\end{tabular}

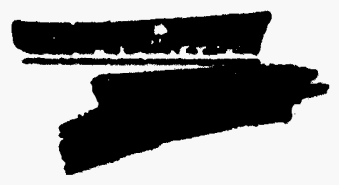


TABLE III

BUTK DENSITY OF ANHYMROUS PLUTONIUM TRICRLORIDE

\begin{tabular}{|c|c|c|}
\hline Run Ident 1ty & $\begin{array}{l}\text { Bulk Dens1ty } \\
\mathrm{g} / \mathrm{cc} \\
\end{array}$ & Remarks \\
\hline Batch Chlor 1nator & 2.58 & Average of 14 randon \\
\hline \multicolumn{3}{|l|}{ Pyrex Chlorinator } \\
\hline $\begin{array}{l}30-1 \\
30-2 \\
30-3 \\
30-5 \\
30-6 \\
30-7 \\
30-8 \\
30-10 \\
30-10 A\end{array}$ & $\begin{array}{l}2.28 \\
2.00 \\
2.32 \\
2.96 \\
2.99 \\
2.88 \\
2.79 \\
2.41 \\
2.85 \\
\end{array}$ & $\begin{array}{l}\text { Average of } 2.02,1.95 \\
\text { Average of } 2.88,3.04 \\
\text { Average of } 2.96,3.02\end{array}$ \\
\hline & 2.61 & Averago \\
\hline
\end{tabular}

Demonstration Chlorinator

$\begin{array}{ll}4-7-2 & 2.58 \\ 4-28-2 & 2.40 \\ 5-19 & 2.20 \\ 6-15-1 & 2.36 \\ 6-26 & 2.75 \\ 6-15 \text { and }-16 & 2.15\end{array}$

2.41 Average

\section{Purligy}

Labaratory analyoes (Tablo IV) of the trichlorido Indicate an average chlorination of 97.3 percent of theoret1cal, carresponding to the formuln $\mathrm{PuCl}_{2.92}$.

The 1mpurities in the powder are shown in Tables V, VI, and VII 1n relationsh1p to tho purity of the feed materiul and of the resulting metal. The chlorination step did not contaminate the 


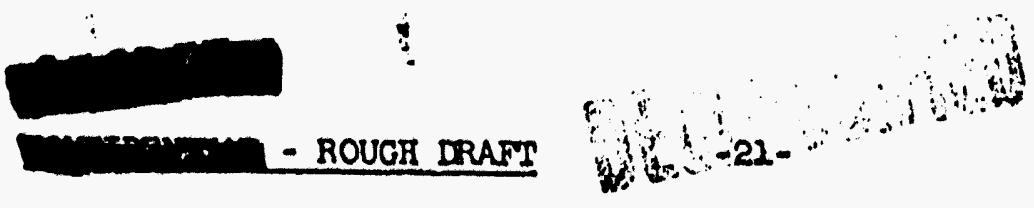

EW -61565 RD

powder to any troublesame extent. In the case of elements forming volatile chlorides, an improvement in purity is 1ndicated.

The reduction of the trichlor1de to metel indlcated the powder
was satisfactory. $(14)$.

\section{FUTURE WORK}

Same additional runs on the demonstration chlorinator are needed to determine 1ts maximum capacity. Beating of the upper end of the Hastelloy B tubo and supplyine part of the phosgene at that end would 1ncrease the effective length of the chlorinator.

Among varlous possible studies to surther improve the process, there 18 one line of 1nvest1gation wh1ch shows most promise. Dry plutonlum oxalate was chlorinated by phosgene at a temperature of $250 \mathrm{C}, 200$ degrees lower than oxide chlorination. At this temperature, the addition of acrew drive through the chlorinator could certalnily be tolerated without fear of corrosion problems. Th1s would eliminate vibrator resoname and chloride lump problems by provlding positive control of powder flow.

\section{v. ACGONWLEDGEOENTS}

H. H. Hopkins, Jr., managed and gulded this and other related studies. H. W. Crocker dosigned the chlorlnators and the gloved hoods containlng them. The provision of dry atmosphere for the Pyrex cont1nuous unlt is credited to R. R. Bond. Indtial chlorinations were by N. 8. Wing, now of Finfsbed Products Operation Analytical Control. W. L. Walker of ILO Cremlcal Development performed the corrosion testing. Ceorge Rey, also of BIO Cherical Development, assisted in filter and scrubber testing and designe. I. F. Lust, now of HLO Analyt1cel Laboratorles, geve valuable help in the chlorination work. The oxide feed for the demonatration chlorinator was prepured by C. J. Berplund as needed. 
TABTS IV

CIIORIDE/PLUTOSRUM RATIO BY LABORATORY ARATYSES OF PLUZOIIUY

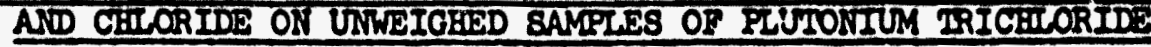

Run Ident1ty

Betch Chlor 1nators

Pyrex Chlor Inator

$30-1$

$30-2$

$30-3$

$30-4$

$30-5$

$30-6$

$30-7$

$30-8$

$30-9$

$30-10$

$30-2 \times 14$

$30-11$

$30-13$
Q2/Pu

2.92

2.99

2.81

2.64

2.78

2.68

2.70

2.84

2.84

3.07

2.78

2.90

2.91

2.91

2.83

Remarke

Average of 59 batch chlorinatlons

Average of 13 Pyrex Chlorinator runs.

Demonstration Chlorinator

$4-7-1$
$4-7-2$
$4-17$
$4-22$
$4-28-1$
$4-28-2$
$5-4$
$5-6$
$5-13$
$5-19$
$6-4$
$6-15$
$6-16$
$6-26$
$7-8$
$7-9$

3.04

2.95

2.96

2.83

2.92

2.94

2.95

2.91

3.09

3.07

3.03

3.00

3.08

3.04

3.10

2.94

2.99 Average of 16 Demonstration Chlorinator rune

2.92 Average of 88 samples of $\mathrm{PuCl}_{3}$

NOts: Accuracy of each estimated at \pm 10 percent. 

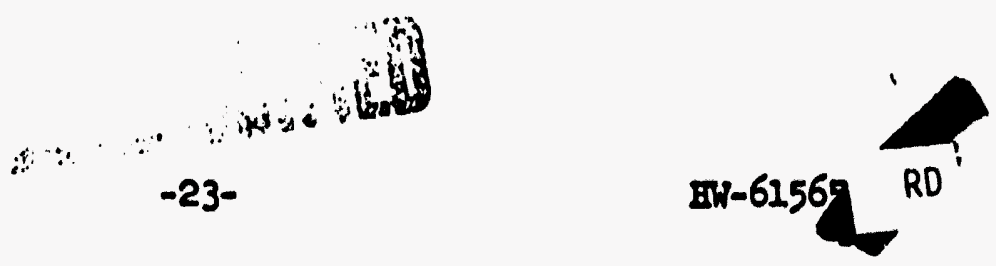

\section{TABTE V}

\section{PLUTONIUM TRICIICORTDS IMPURITIES}

A compar18on of typlcal spectrographle analyses of oxdde, chloride, and wetal when the Pyrex continuous chlorinator was used with phosgene at 450 - $500 \mathrm{C}$. Velues are parts Impurity per mill1 on parts plutonlum.

\begin{tabular}{|c|c|c|c|}
\hline Impur 1ty & uxide & Chlor1de & Netal \\
\hline Ag & L2 & 12 & I2 \\
\hline Al & 5 & 16 & 13 \\
\hline$A B$ & $=$ & $=$ & - \\
\hline B & L2 & I2 & 2 \\
\hline Be & - & - & - \\
\hline B1 & - & - & - \\
\hline $\mathrm{Ca}$ & 5 & 16 & 13 \\
\hline $\mathrm{cd}$ & - & - & - \\
\hline$C r$ & 20 & 10 & 5 \\
\hline $\mathrm{Cu}$ & 10 & 20 & 10 \\
\hline $\mathrm{Fe}$ & 200 & 50 & L50 \\
\hline Ge & - & - & 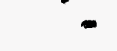 \\
\hline $\mathbf{K}$ & - & - & - \\
\hline La & - & - & - \\
\hline L1 & - & - & - \\
\hline Mo & 50 & 50 & 200 \\
\hline Mo & 50 & - & - \\
\hline Non & 20 & 20 & 50 \\
\hline $\mathrm{Na}$ & 100 & 100 & 20 \\
\hline$N 1$ & 200 & 200 & 50 \\
\hline $\mathbf{P}$ & - & - & - \\
\hline Po & 2 & 2 & 10 \\
\hline s1 & 20 & 20 & 10 \\
\hline Sn & 12 & I2 & - \\
\hline TI & - & - & - \\
\hline $\begin{array}{l}V_{2 n} \\
2 n\end{array}$ & 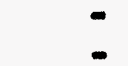 & - & 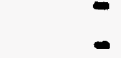 \\
\hline
\end{tabular}

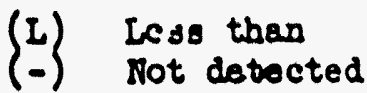


TABTE VI

\section{FLUTOIIUM IRICERORIDE IMPURITIISS}

A comparison of typlcal spectrographlc analyses of oxtde, chloride, and metal when the Bastelloy B demonstration chlorinstor was used with phoscene at $500 \pm 25 \mathrm{C}$. Values are parts impurity per mill10n parts plutondum.

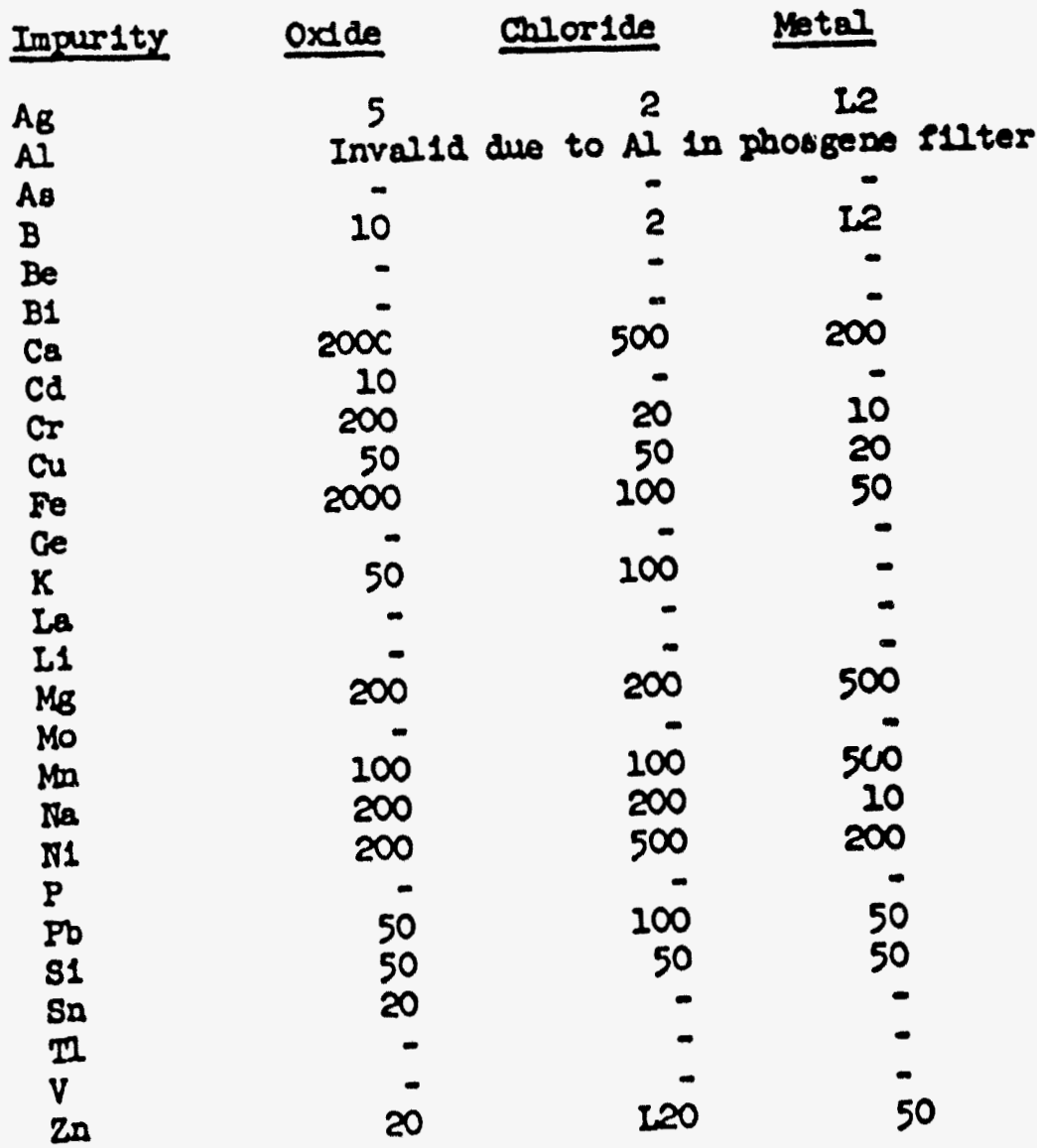

(L) Less than

(-) Not detected 


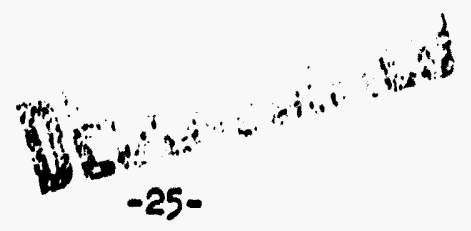

TABIS VII

\section{PLUTONIUM TRICHLORIDE DMPURITIES}

A comparison of typlcal opectrographlc analyses of nitrate solut1on, oxide, and chloride when the Bastelloy B demonotration chlorinator vas uned w1th phosgen at $300 \pm 25 \mathrm{C}$. Values are parts Impurity per ulll10n parts plutonium.

\begin{tabular}{|c|c|c|c|}
\hline Impur 1ty & N1trate & Oxdde & Chloride \\
\hline $\begin{array}{l}\mathrm{Ag} \\
\mathrm{AI}\end{array}$ & $\begin{array}{r}\text { I5 } \\
5\end{array}$ & L2 & $\begin{array}{l}2 \\
5\end{array}$ \\
\hline $\overrightarrow{A B}$ & $?$ & - & 5 \\
\hline B & 5 & - & L2 \\
\hline Be & - & & 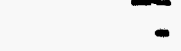 \\
\hline B1 & 5 & - & - \\
\hline $\begin{array}{l}\mathrm{Ca} \\
\mathrm{Cd}\end{array}$ & $\begin{array}{r}50 \\
10\end{array}$ & & 50 \\
\hline $\begin{array}{l}\text { Cd } \\
\text { Cx }\end{array}$ & 1000 & 100 & - \\
\hline $\begin{array}{l}\mathrm{Cr} \\
\mathrm{Cu}\end{array}$ & 20 & 100 & 50 \\
\hline $\begin{array}{l}\mathrm{Cu} \\
\mathrm{Fe}\end{array}$ &,$\infty$ & 5 & 20 \\
\hline $\begin{array}{l}\mathrm{Fe} \\
\mathrm{Ce}\end{array}$ & $\begin{array}{r}2000 \\
20\end{array}$ & L 100 & 50 \\
\hline $\begin{array}{l}\mathrm{Ce} \\
\mathbf{K}\end{array}$ & $\begin{array}{r}20 \\
500\end{array}$ & - & - \\
\hline $\begin{array}{l}\text { K } \\
\text { La }\end{array}$ & $\begin{array}{r}500 \\
-\end{array}$ & 59 & 100 \\
\hline L1 & 50 & - & - \\
\hline MB & 50 & 20 & 5 \\
\hline Mo & - & 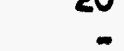 & 50 \\
\hline m & 100 & 20 & 50 \\
\hline $\mathrm{Na}$ & 1000 & 100 & $\begin{array}{r}50 \\
200\end{array}$ \\
\hline$N 1$ & 500 & 100 & 500 \\
\hline$P$ & - & - & \\
\hline Pb & 50 & 50 & 20 \\
\hline S1 & 10 & 20 & 20 \\
\hline Sn & 5 & L5 & L5 \\
\hline TI & - & - & - \\
\hline V & 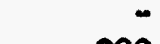 & - & - \\
\hline $2 \mathrm{n}$ & 200 & 20 & L2O \\
\hline
\end{tabular}

(L) Less than

(2) Creater than

No analyses for slements not 118 ted 


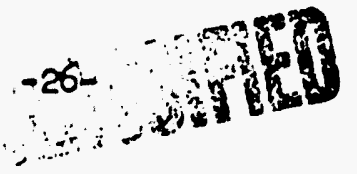

VI. BIBITIOCRAPHY

(1) Carner, C. S., The Preparation of Plutonium Trichloride, IA-112. July 24, 1944 (Declassifled).

(2) Kennedy, J. W. and C. S. Sulth, Spcc1al Report Presented At July Meet1ng W1th C. A. Thamas On Final Puriflcation And Metalluray Or 49, LAMS-112. July 14, 1944 (Secret).

(3) LangB, M. P. and J. MIlsted, The Preparat1on of Mill 1gram quant1ties of Plutontum Metal And Some Observations On Its Propert1es, CRC-490. Undated (Confident1al).

(4) Seabor8, G. T. and I. Yarle, Rev1ew of the Vapor-Phase Chlorinat1on of $\mathrm{PuO}_{2} \cdot \mathrm{H}_{2} \mathrm{O}, \mathrm{MUC}-\mathrm{GTS}-783$. July 14, 1944 (secret).

(5) Anderson, J. M. et al, Preparation of Plutonfum Campounds For Reduction To Metal, IA-440. October 24, 1945 (Secret).

(6) Garner, C. S., Chapter 4 of Chemlstry of Uranium And Plutontum, IA-1100. Issued Apr1] 20, 1950, F1rst Drart Issued June 27, 1947 (Secret).

(7) E. I. Crristensen, Preparation of Anhydrous Plutonium Tr 1chlor 1do, La-1431. October 15, 1952 (Declass1f1ed).

(8) Tolley, W. B., Plutonlum Tr1chlor1de: Preparat1on By React1on W1th Phosgene Os Carbon Tetrachloride, And Bamb Reduction to Metal, EW-30121. December 3, 1953 (Secret).

(9) Freeman, J. H. and M. L. Smlth, The Preparation Of Anhydrous Inorganlc Chlorides By Dehydration W1th Th1onyl Chlor1de, AEREGP-R-2282. August, 1957 (Unclass1fled).

(10) Harder, B. R., F. Hudswell, and K. L. WLIKInson, The Preparat1on Of Anhydrous Plutonlum Tr1chlor1de, ARRE-C-R-2445. December, 1957 (Uncles81f1ed).

(II) Budaev, I. V. and A. N. Volsky, Irrest1gat1on or React1ons of Chlar1nating Uran1um Dloxdde And Plutonfum Dioxdde By Carbon Tetrachlor1de, A/ Conf. 51/P/2195, USSR at Geneva Conference. August 25, 1958.

(12) Eopkins, H. H., Jr., by B. W. Crocker, A Plan For Piuton1um ir1. chlor1de Process Developient, BH-54874. Tebruary 6, 1958.(Becret)

(13) Bopkins, H. B., Jr., Status or Plutonium Trichloride Process Development, $\mathrm{HW}-57498$. September 17, 1958 (Secret)

(14) Solne, T. S., Batch Reduct1ou or Plutonium Tr1chlor1de, EW-61564 RD. August 14, 1959 (Secret - Rough Draft). 

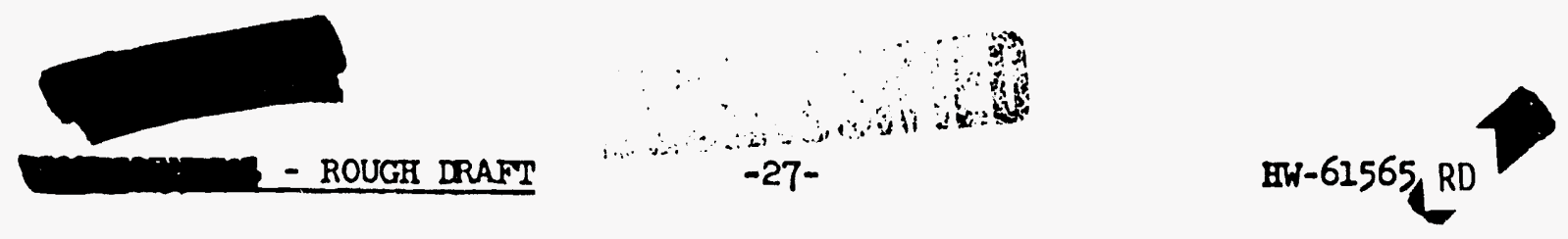

(15) Smtth, R. C., Recovery of Plutontum From Chlor1de Slag And Cruc1ble, EW-61577. August 14, 1959 (Conf1dent18l)

(16) Stock, A. and W. Wustrow, Decomposition of Carbonyl Chloride By Beat, 2. anor8. Chem. $147,245-55$ (1925).

(17) Bodenstein, M. and H. Plaut, Thermal Format1on And Decompos1tion of Phosgene, Z. phys1k. Chem. 210, 399-416 (1924).

(18) Rey, Ceorge, Prototype Button I1ne Powder Traps, EW-59381. March 15, 1959 (Unclassifled).

(19) Lust, L. F., The Analyses of Exhaust Products In The Chlorination of Plutonium W1th Phosgene, HW-59749. March 24, 1959 (Declabs1f1ed).

(20) Rey, Ceorge, Chlorinator Orf-Gas Scrubber, Undocumented. December 22, 1958 (Confident1al).

(21) Zacharleson, W. H., Cli-2069 (A-3011). August, 1944 (Declass12:ed).

(22) Brady, B., CK-1701. June, 1944 (Declass1f1ed).

(23) Handbook Of Chem1stry And Phys1ca, 30th Ed1t1on (1947) Chem1cal Rubber Publish1ng Company, Page 1926.

(24) Brown, C.L., Neutron 15810n Rate Of PuCl3, $\mathrm{EH}-58837$. January 13, 1959 (secret)

\section{APPENDIX}

\section{Phosgene Safety}

Phosgene, or carbonyl cblor1de, formula $\mathrm{COCl}_{2}$, was notorlous as a war gas. Safety measures whlch are adequate for handling cylinders of hydrogen fluoride are rilly adequate for phosgene. Complete protection of the eyes, nose, and mouth are required; but the skin 18 not damaged by occasional exposures to traces of phosgene gas.

Rellable fresh-alr masks or Chemox masks are necessary wen the phosgene concentration in air exceeds one part per million. Autconat1c warning devices are avallable to detect gas leakage at this level. A Dav1s phosgene analyzer was used for leak detection. Phosgene leakage may be detected by the distinctive odor of the gas wilch is noticeable at flve parts per million or less. Concentrations of twenty-rive parts per mlllion for one-half hour or longer are dangerous. Phoogede 1 is a primary 1rritant of the respiratory tract. Over-exposures cause coughing and teas formation. Edeme in the lungs may not appear serlous unt1l four, or even $81 x$, hours after over-exposure.

Phosgene 18 supplied in cyllnders in l1quid form at a gas pressure of about $30 \mathrm{pal}$ (gauge) at ronm temperature. The cylinders should never 


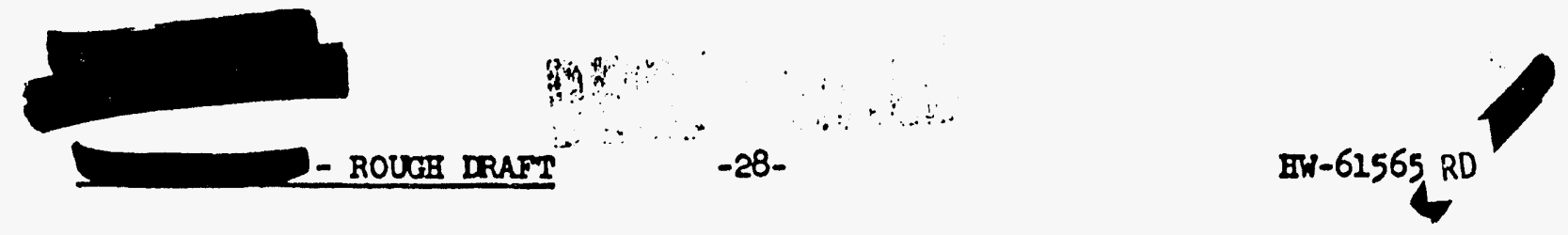

be heated to exceed this pressure. The bolling point 18 8.2 C or $46.7 \mathrm{~F}$. If the cylinder 18 not upright, the 11quid, rather than gas, w1ll flow when the valve is opened. Detalled valve instruction accompanles each cylinder.

Experlence with phosgene has demonstrated that it can be used and handled with safety.

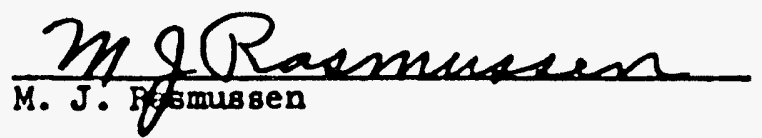




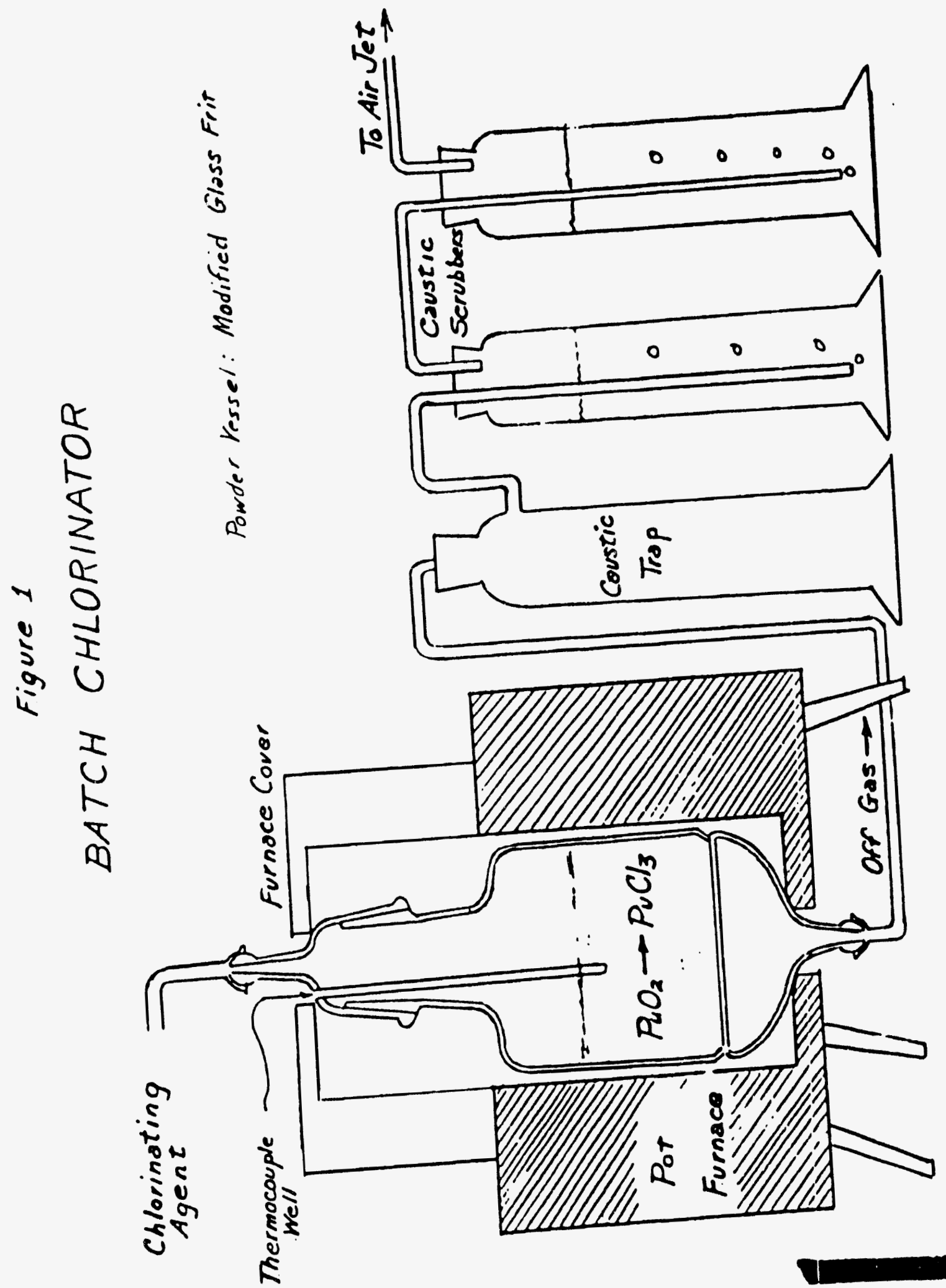

DECLASSIFIED 


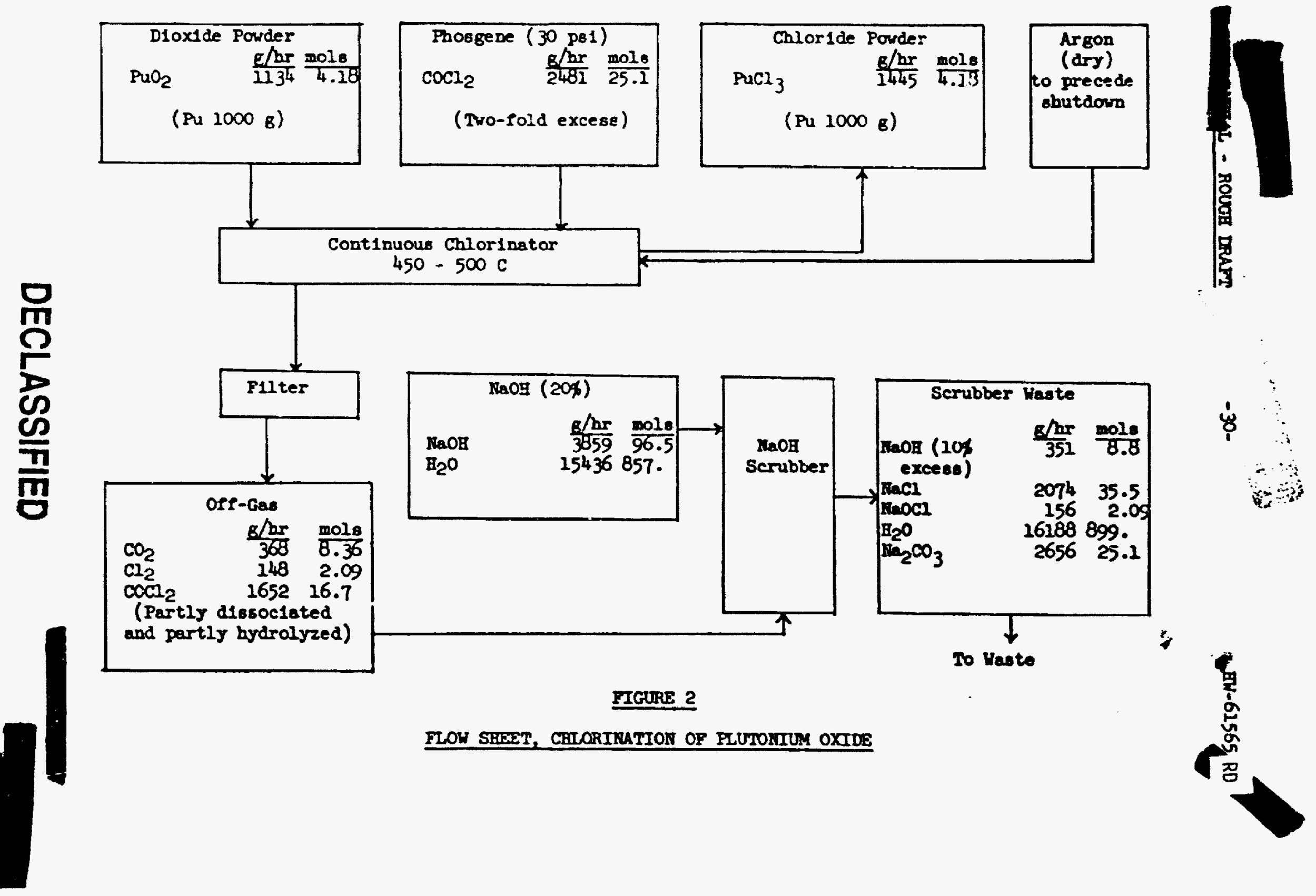


MOURE 3

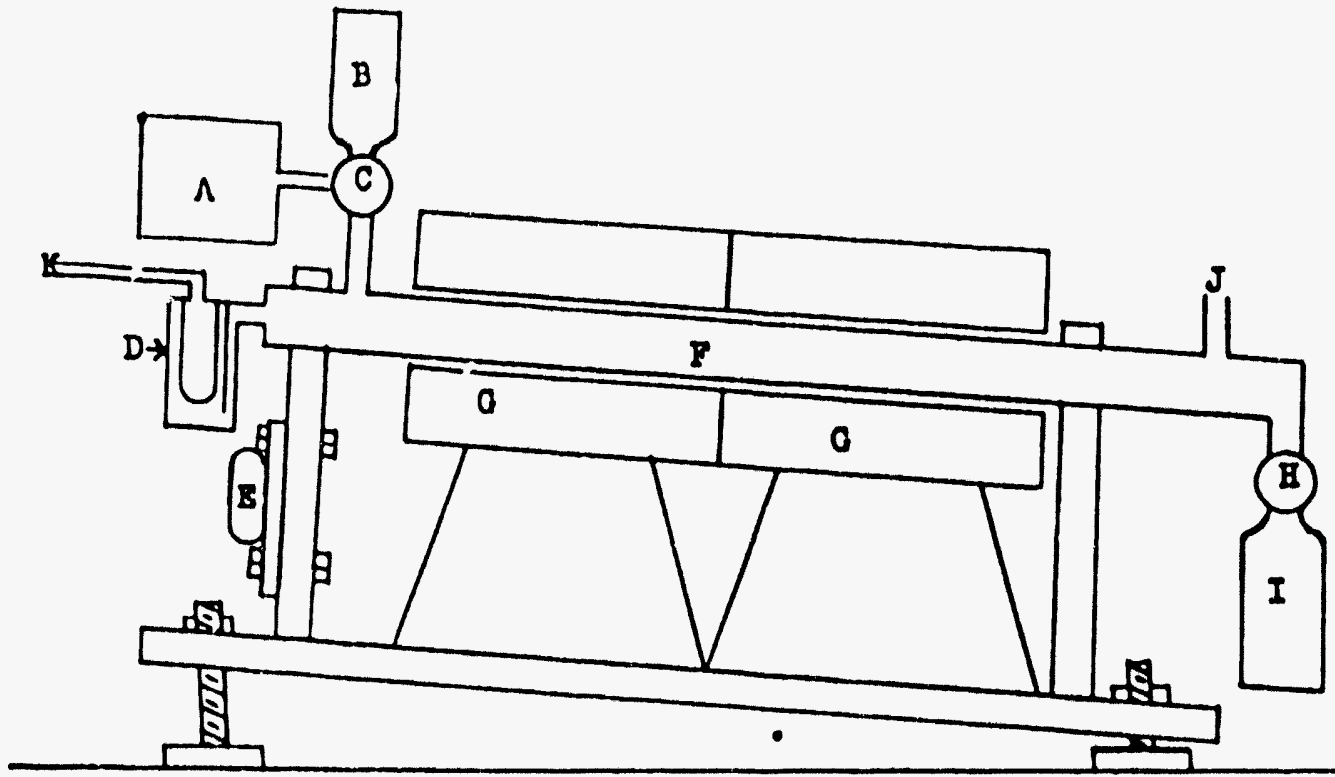

A. Motor to drive valvo C. Controlled by Flexopulse (Eagle S1gnal Corporat1on, Mol1no, Ill1no18) and Motor Control (O. K. Beller, Balt Imore, Maryland).

B. Plutontum oxdde reservolr.

C. Powder valve.

D. Powder trap and ceram1c singer pliter.

E. Vibrator (Model 1-91-0002, V1ta Pack V1brator).

F. Pyrex giese plpe, I" I.D.

G. Electric tube Rurnace (Type 70, Bev1-Duty Electr1c Company, M1lwaukee, W18consin).

B. Powdor valve, manual.

I. Chlor1do recelver.

$\mathrm{J}$. Phosgeno entrance.

K. Orf-gases ex1t to scrubber. 


\section{nisted}

HW-61565,RD

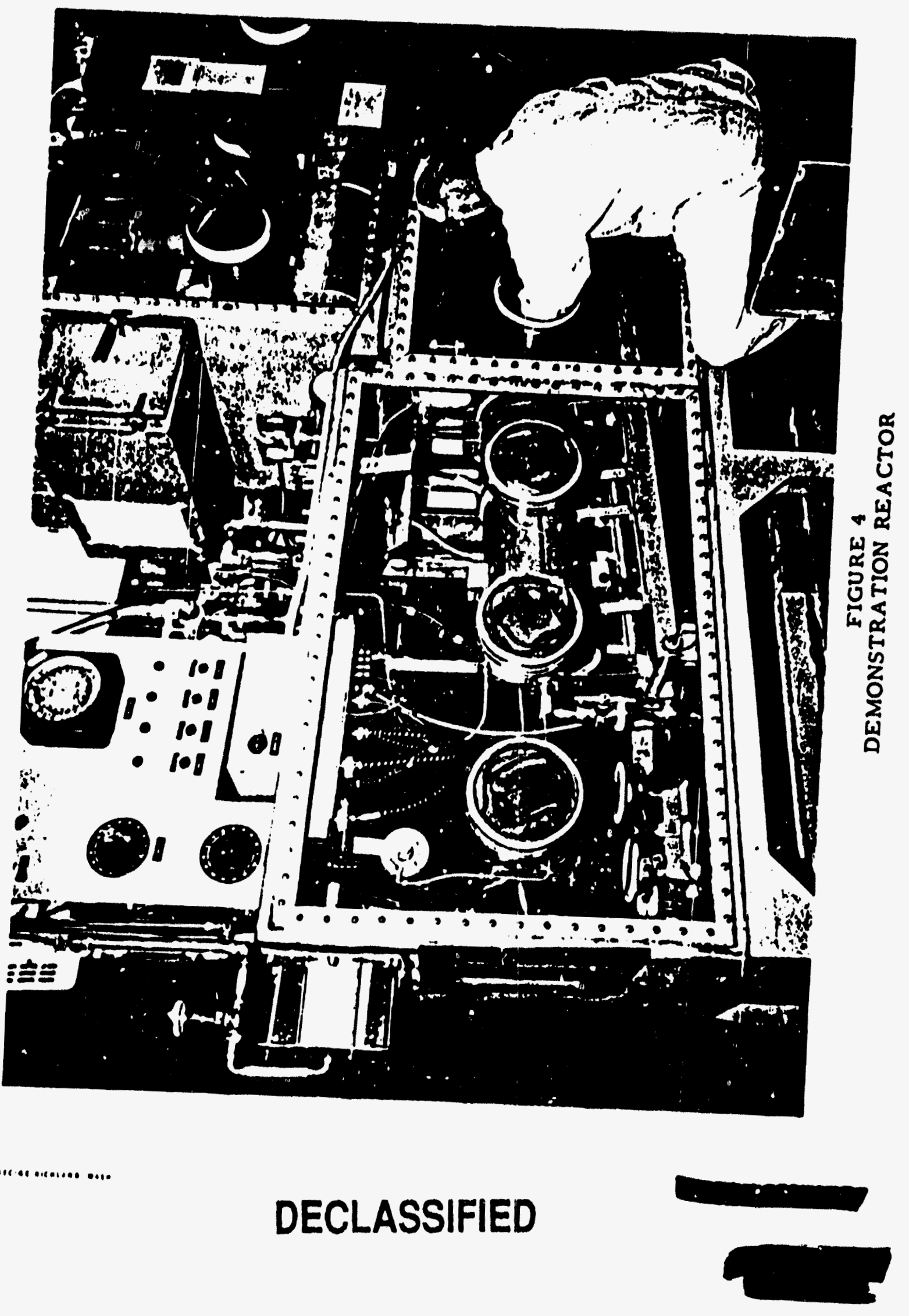




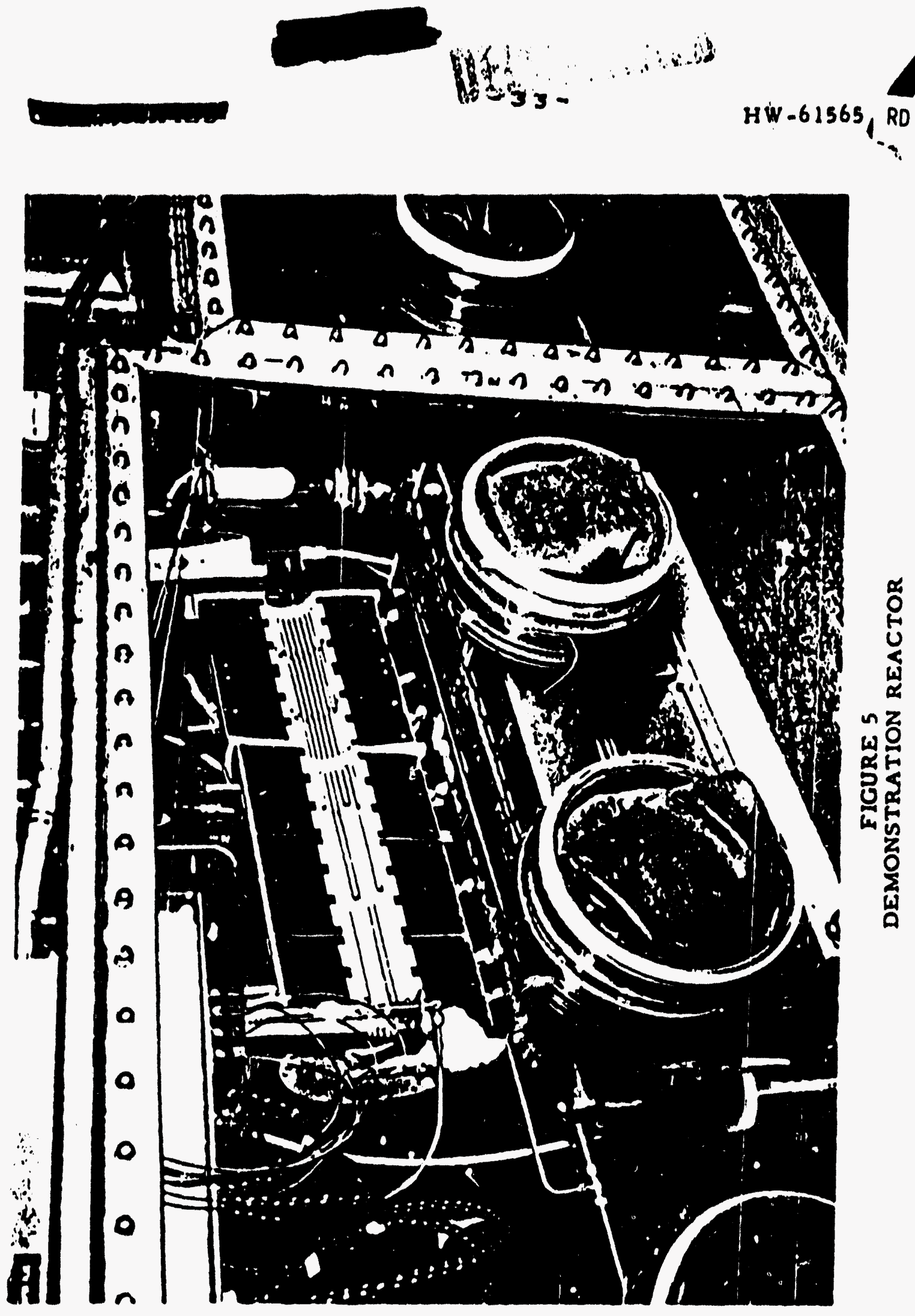

DECLASSIFIED 
Vish

$-34-$

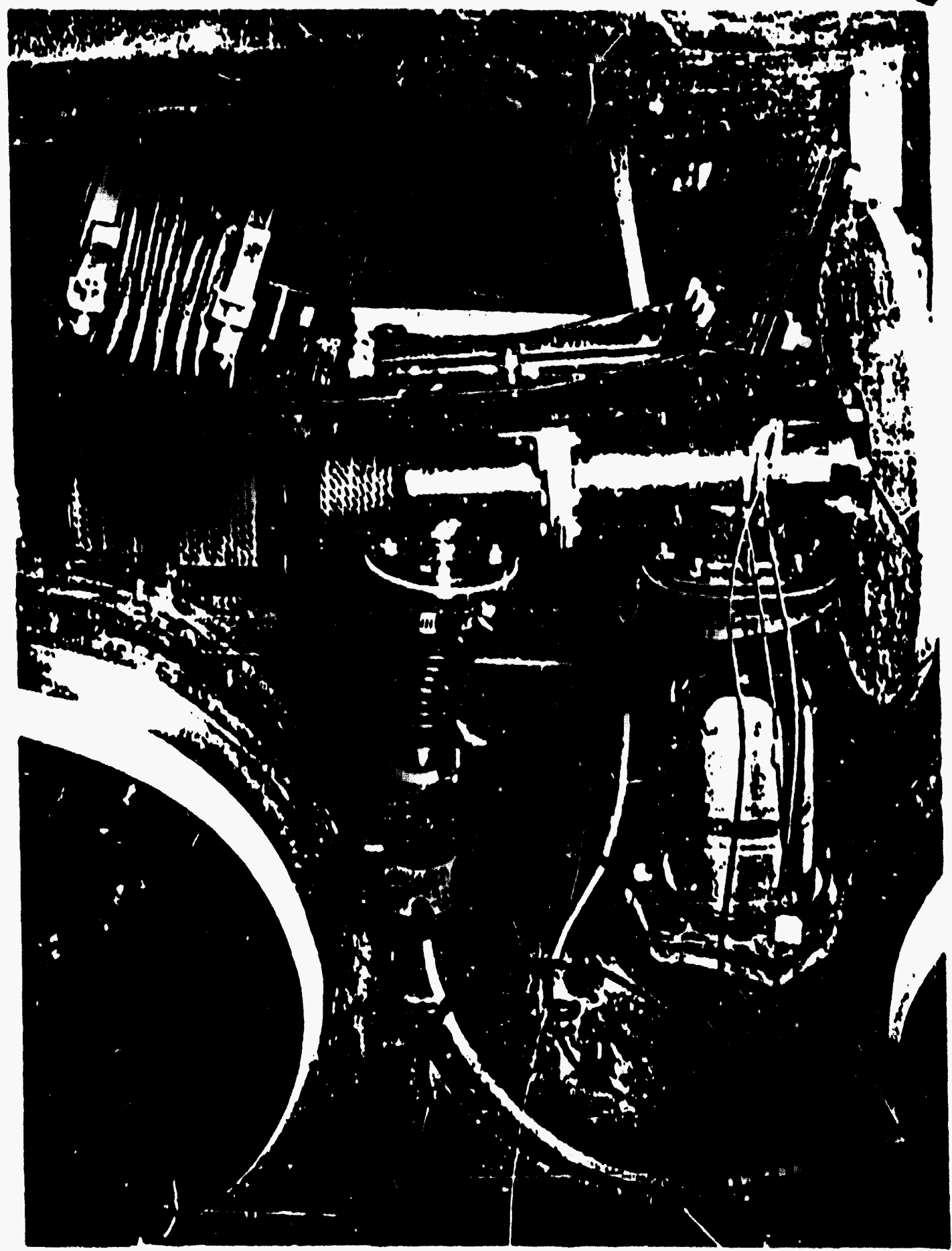

FIGURE 6

DEMONSTRATION RFACTOR

\section{DECLASSIFIED}




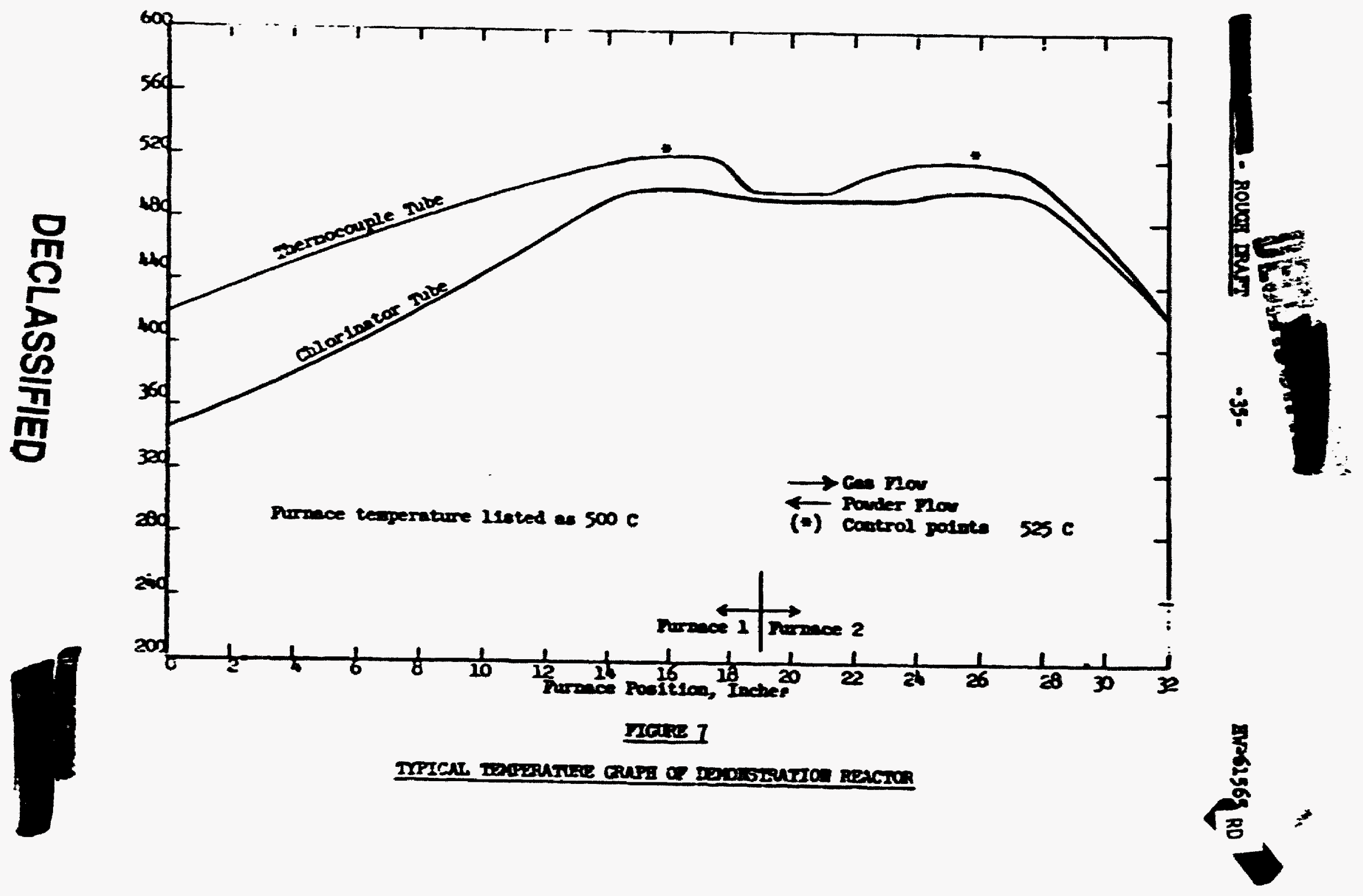




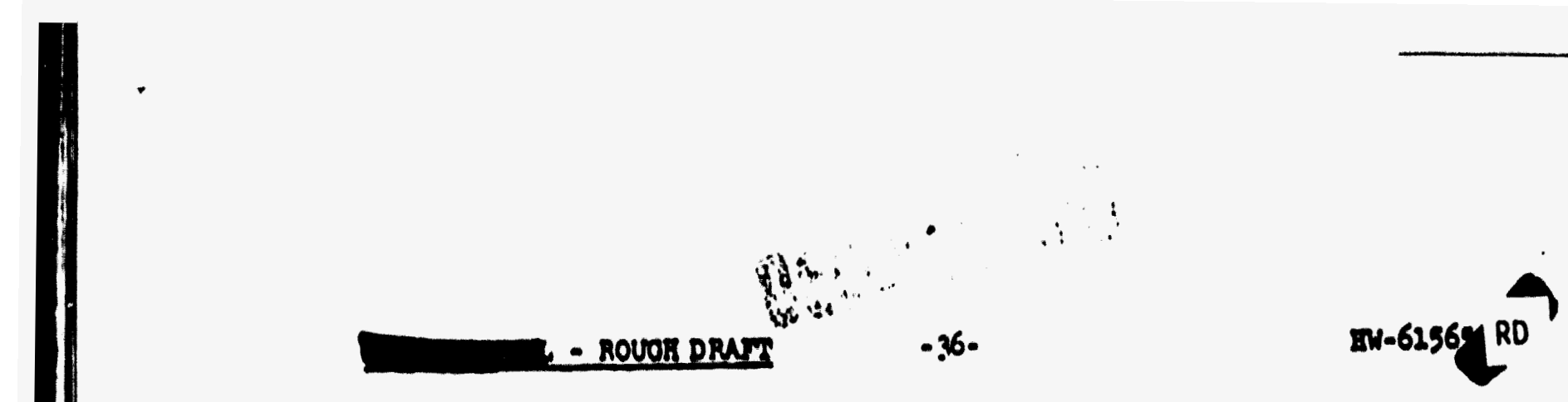

Louns 8

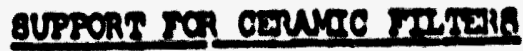

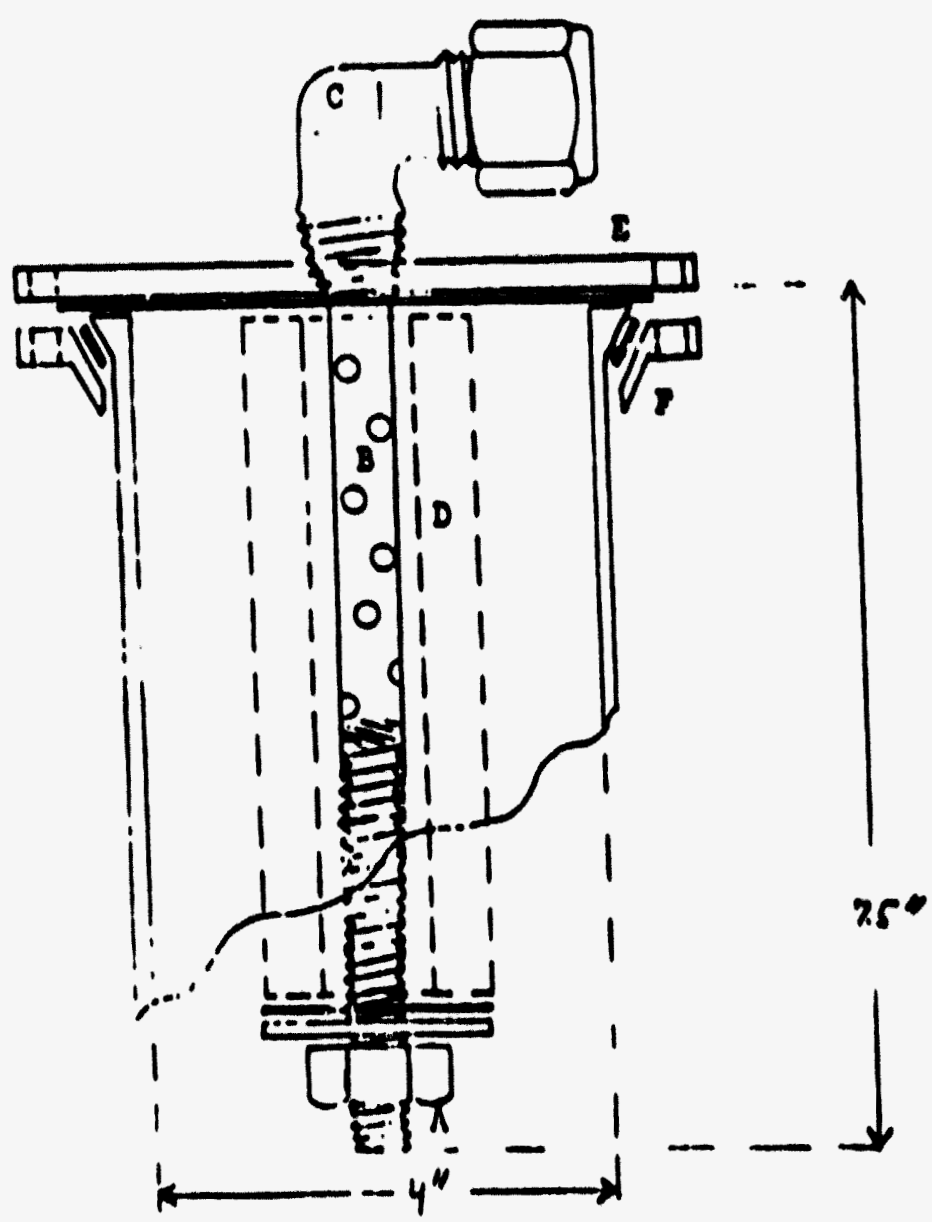

A. Batelloy $C$ 3/8" dlasetor rod, nut, vahor, and slberclese gasket. nod threadad for 3-1/2" to $0^{\circ}$ wo 4 - 6" s1itars.

B. Basto220y C 3/8" O.D. tublne, holos for ene oxit.

C. Elbow, 316 08, 1/2" $5,3 / 3$ " malo NPS wollod to tubles "B", threaded Into nang "Q".

D. Coresto Siter, 1-3/4" 0.D.

C. llastolioy C slanco.

F. Pyrox plpe, 3" alanotor, and ylpo Manos. 
Figure 9

EXHAUST GAS SCRUBBER SYSTEM
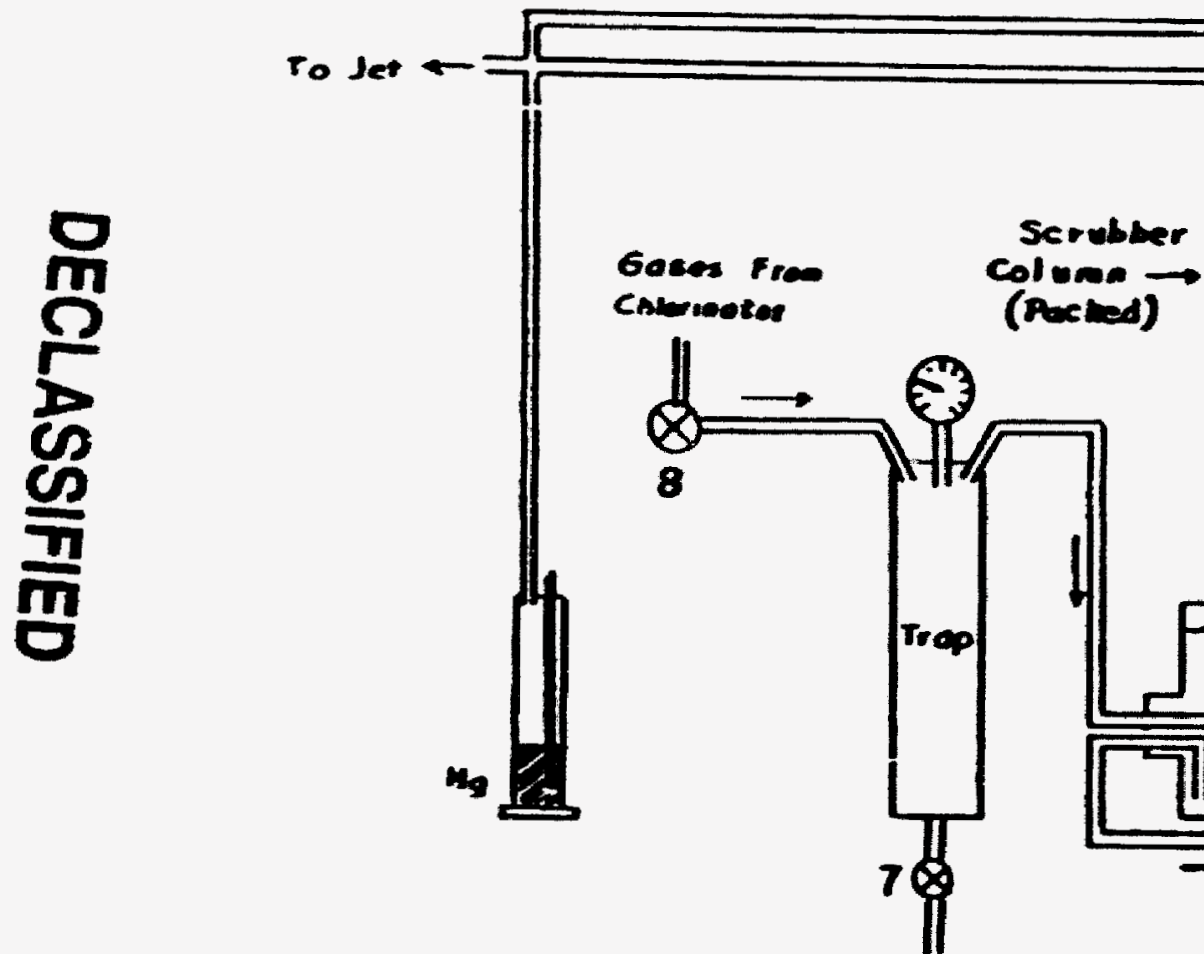

(Acried)
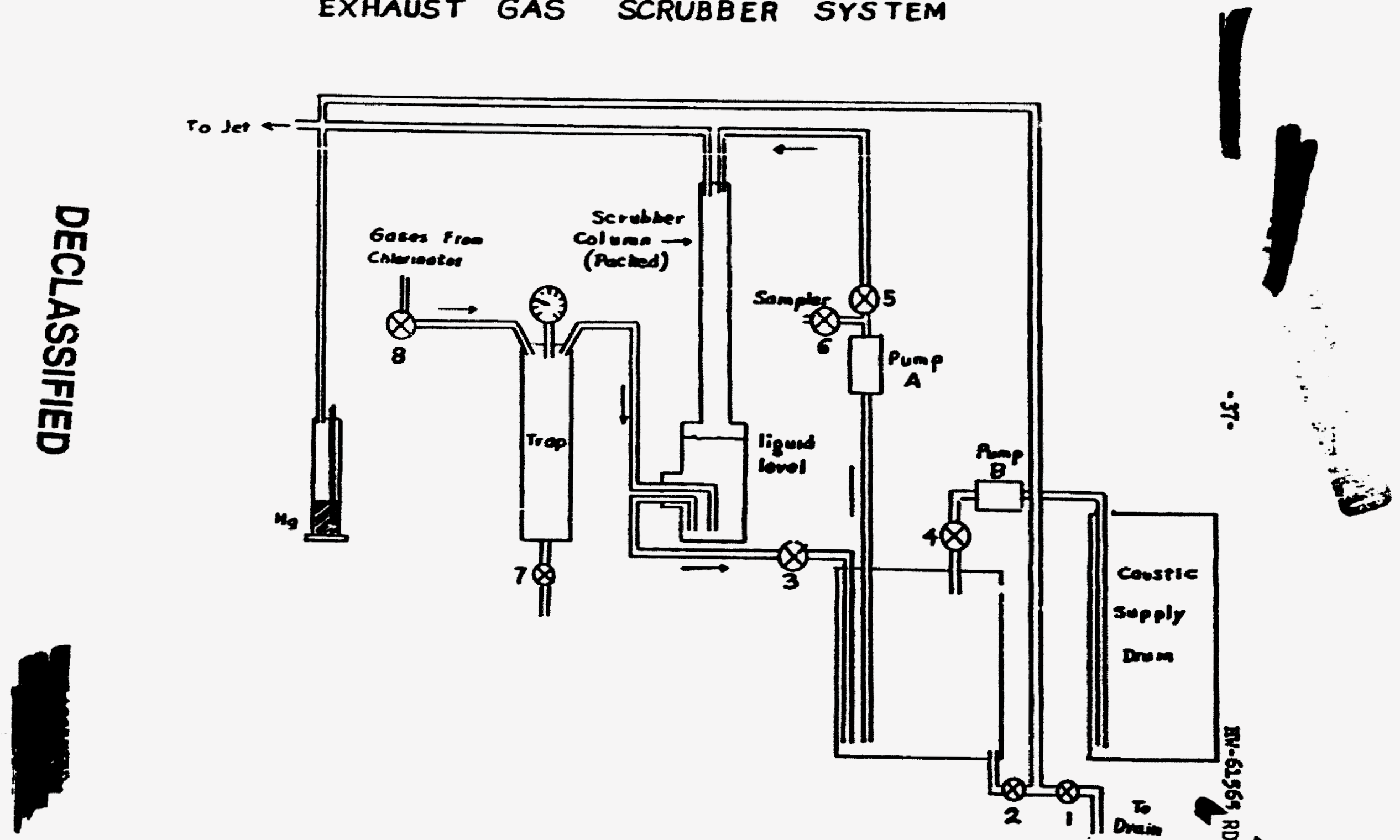


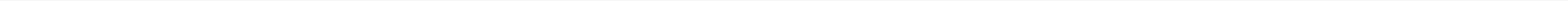

